University of South Florida

DIGITAL COMMONS

Digital Commons @ University of

@ UNIVERSITY OF SOUTH FLORIDA

South Florida

$1-1-2011$

\title{
2011 Work Plan USF St. Petersburg
}

USF

Follow this and additional works at: https://digitalcommons.usf.edu/usf_accountability_reports

\section{Scholar Commons Citation}

USF, "2011 Work Plan USF St. Petersburg" (2011). USF Accountability Reports. 23.

https://digitalcommons.usf.edu/usf_accountability_reports/23

This Article is brought to you for free and open access by the USF Archives at Digital Commons @ University of South Florida. It has been accepted for inclusion in USF Accountability Reports by an authorized administrator of Digital Commons @ University of South Florida. For more information, please contact digitalcommons@usf.edu. 


\section{Update to the}

\section{University of South Florida St. Petersburg}

Work Plan 
Note concerning data accuracy: The Office of the Board of Governors believes that the accuracy of the data it collects and reports is paramount to ensuring accountability in the State University System. Thus, the Board Office allows university resubmissions of some data to correct errors when they are discovered. This policy can lead to changes in historical data. 


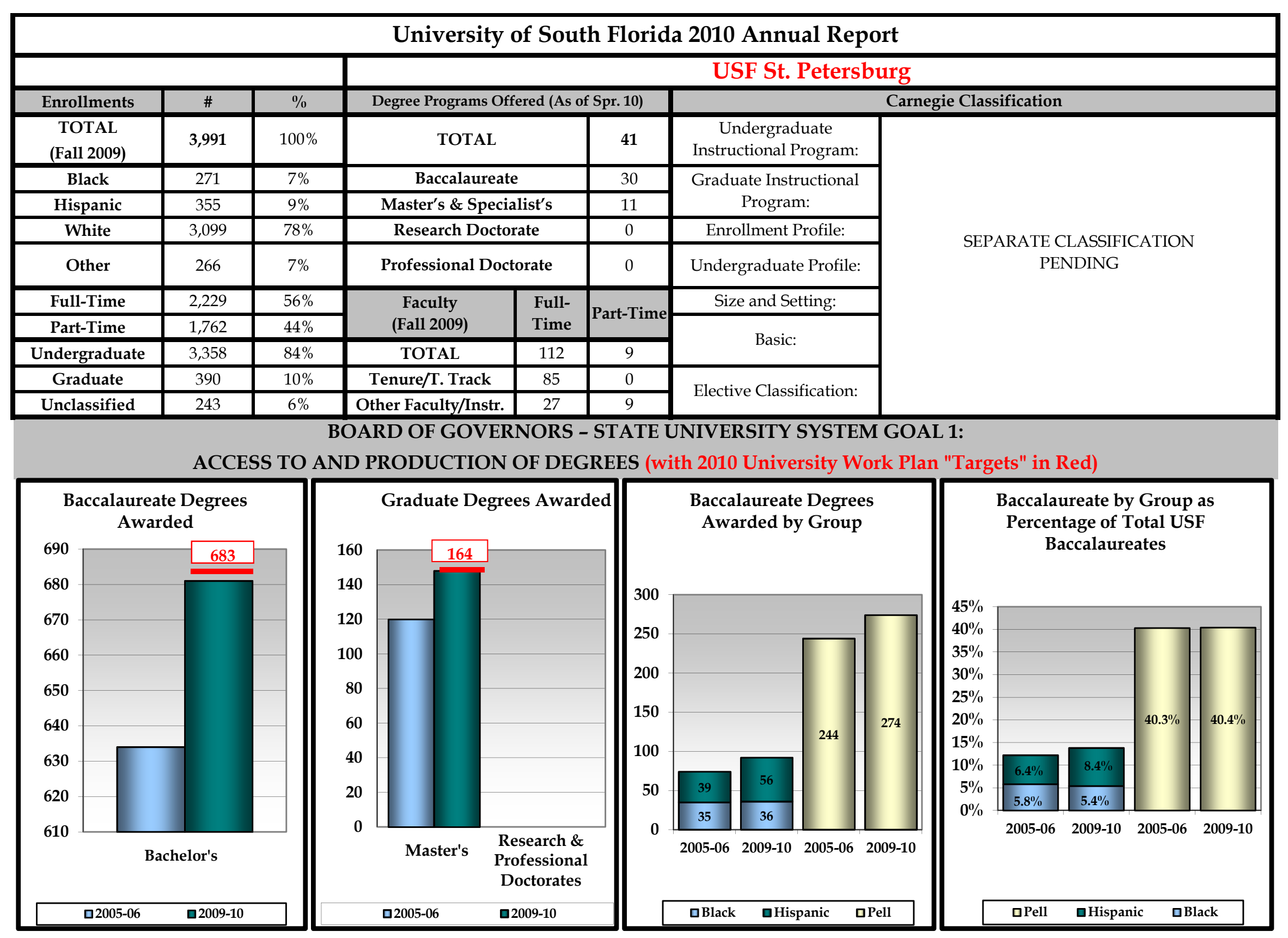

2012 - 2013 Projected Institutional Contributions in RED PRINT. 
BOARD OF GOVERNORS - STATE UNIVERSITY SYSTEM GOAL 2:

MEETING STATEWIDE PROFESSIONAL AND WORKFORCE NEEDS (with 2010 University Work Plan "Targets" in Red)

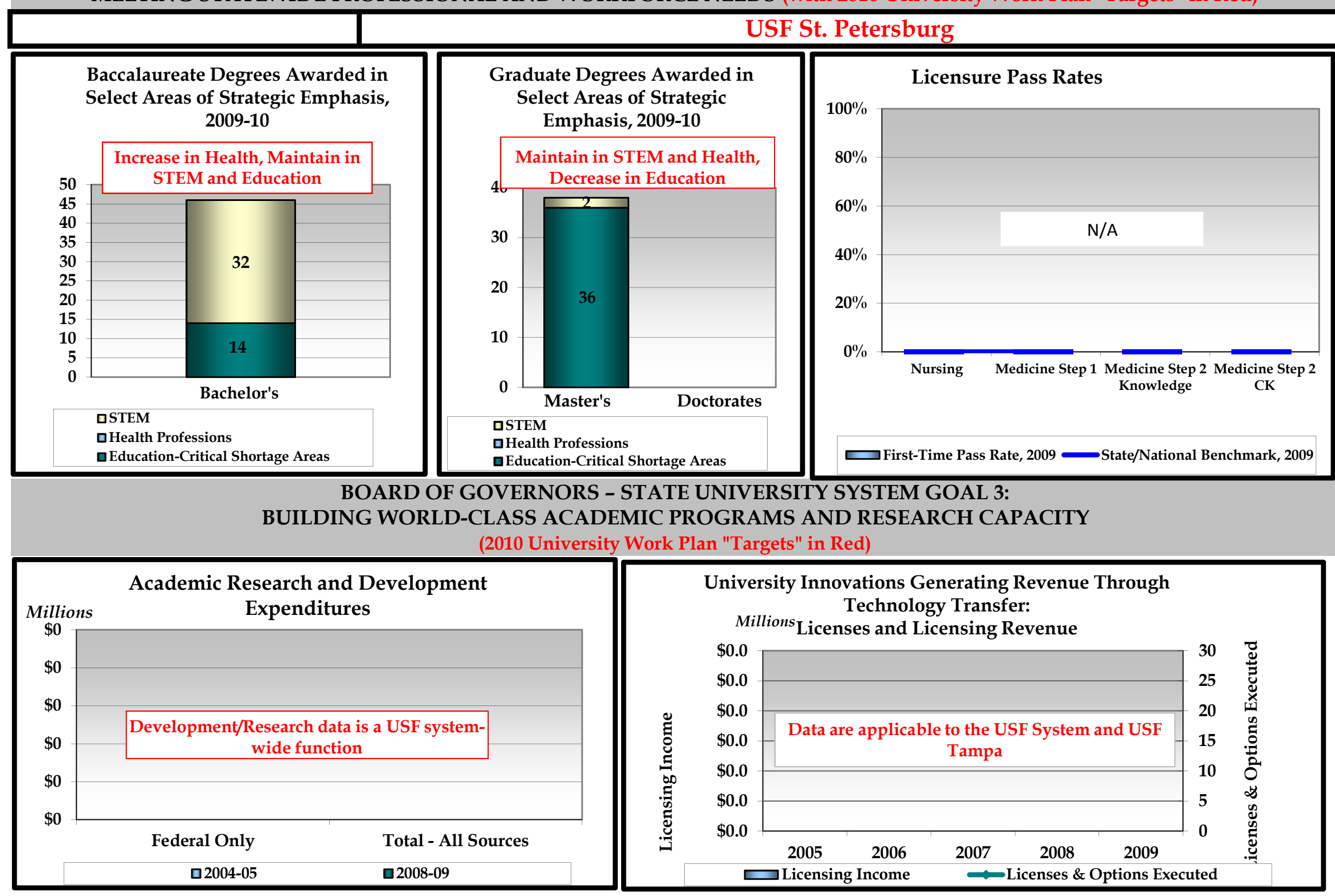

Projected Institutional Contributions in RED PRINT

(2012 - 2013 for TOTAL Degrees in Areas of Strategic Emphasis; 2012 for NCLEX; 2011 -2012 for R\&D, Licences, and Licensing Revenue). 


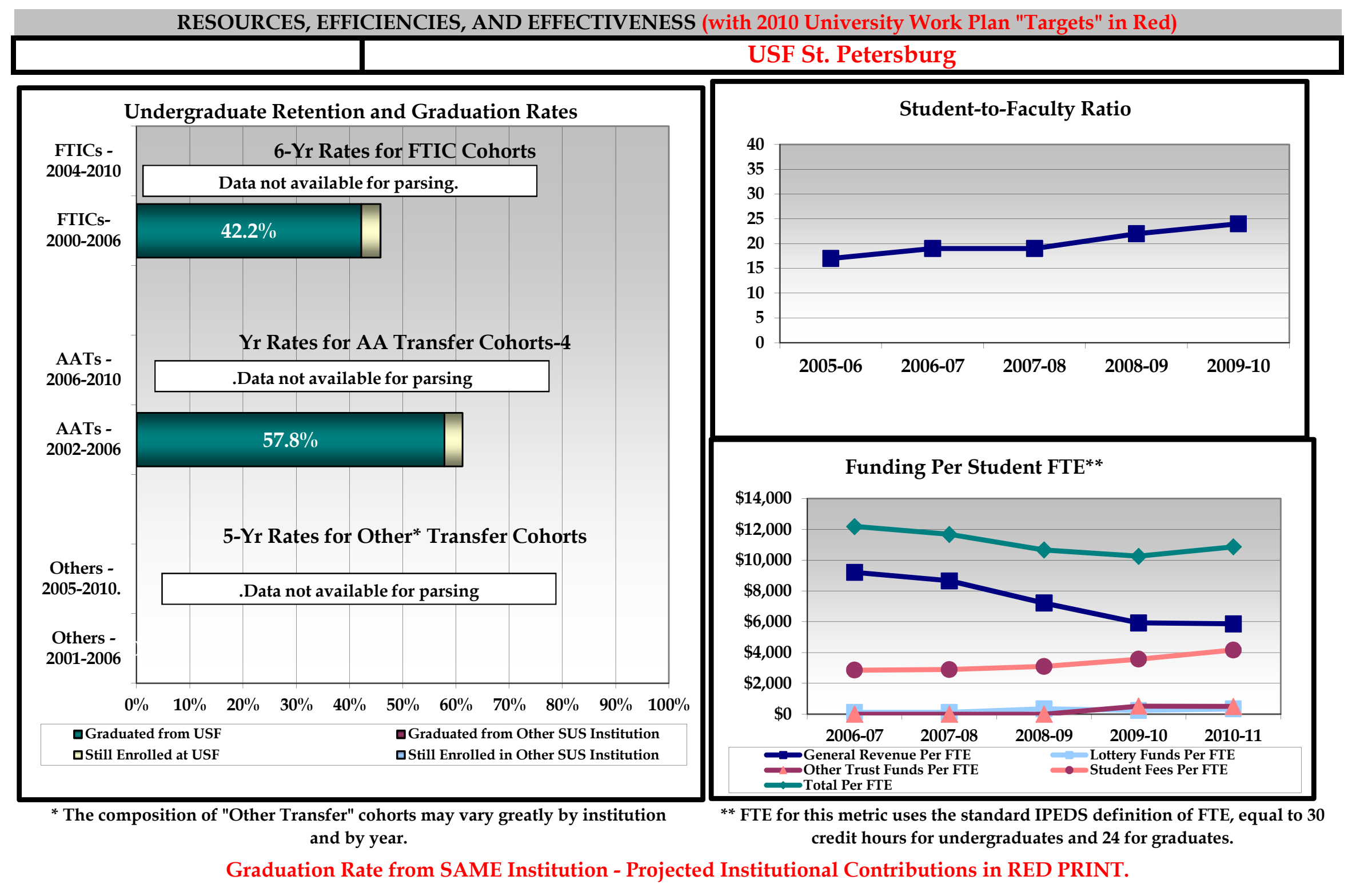




\section{Select Data Tables from the 2009-2010 Annual Report}

* Peer choices should be noted. In cases in which peer data are not available for a specific metric, but are available for a related metric, an institution might want to note such in the "Comparison with Peers" row.

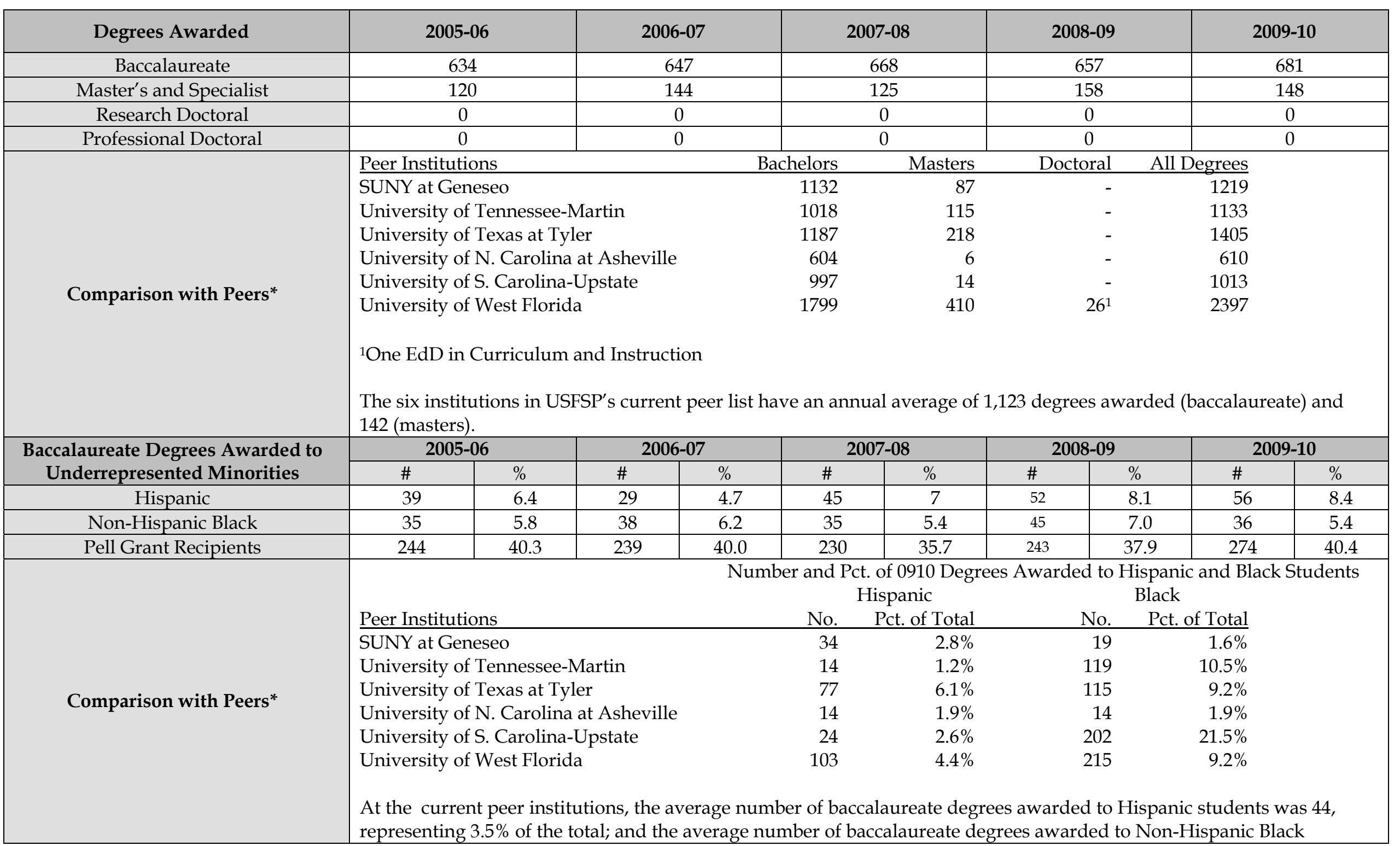




\begin{tabular}{|c|c|c|c|c|c|c|c|c|c|c|}
\hline & \multicolumn{10}{|c|}{$\begin{array}{l}\text { students was 114, representing } 9.0 \% \text { of the total. USFSP compares favorably to peers in degrees awarded to Hispanic } \\
\text { students but lags somewhat in degrees awarded to non-Hispanic Black students. It is notable that about } 40 \% \text { of the } \\
\text { total baccalaureate degrees at USFSP are awarded to Pell grant recipients. }\end{array}$} \\
\hline $\begin{array}{c}\text { Degrees Awarded in Select Areas } \\
\text { of Strategic Emphasis }\end{array}$ & \multicolumn{2}{|c|}{ 2005-06 } & \multicolumn{2}{|c|}{ 2006-07 } & \multicolumn{2}{|c|}{ 2007-08 } & \multicolumn{2}{|c|}{ 2008-09 } & \multicolumn{2}{|c|}{ 2009-10 } \\
\hline STEM (Baccalaureate) & \multicolumn{2}{|c|}{42} & \multicolumn{2}{|c|}{26} & \multicolumn{2}{|c|}{30} & \multicolumn{2}{|c|}{30} & \multicolumn{2}{|c|}{32} \\
\hline STEM (Graduate) & \multicolumn{2}{|c|}{0} & \multicolumn{2}{|c|}{0} & \multicolumn{2}{|c|}{0} & \multicolumn{2}{|c|}{1} & \multicolumn{2}{|c|}{2} \\
\hline Health Professions (Baccalaureate) & \multicolumn{2}{|c|}{0} & \multicolumn{2}{|c|}{0} & \multicolumn{2}{|c|}{0} & \multicolumn{2}{|c|}{0} & \multicolumn{2}{|c|}{0} \\
\hline Health Professions (Graduate) & \multicolumn{2}{|c|}{0} & \multicolumn{2}{|c|}{0} & \multicolumn{2}{|c|}{0} & \multicolumn{2}{|c|}{0} & \multicolumn{2}{|c|}{0} \\
\hline Education-Critical Shortage (Bacc.) & \multicolumn{2}{|c|}{16} & \multicolumn{2}{|c|}{18} & \multicolumn{2}{|c|}{12} & \multicolumn{2}{|c|}{15} & \multicolumn{2}{|c|}{14} \\
\hline Education-Critical Shortage (Grad.) & \multicolumn{2}{|c|}{38} & \multicolumn{2}{|c|}{33} & \multicolumn{2}{|c|}{41} & \multicolumn{2}{|c|}{54} & \multicolumn{2}{|c|}{36} \\
\hline Comparison with Peers* & $\begin{array}{l}\text { Number } \\
\text { Peer Inst } \\
\text { SUNY at } \\
\text { Universit } \\
\text { Universit } \\
\text { Universit } \\
\text { Universit } \\
\text { Universit } \\
\text { Using CI } \\
\text { institutio } \\
\text { degree of } \\
\text { degrees b } \\
\text { single ba }\end{array}$ & $\begin{array}{l}\text { and } \mathrm{Cr} i \\
\text { eo } \\
\text { ennesse } \\
\text { exas at } \\
\text {. Caroli } \\
\text { Carolir } \\
\text { Jest Flor } \\
\text { s for ST } \\
\text { TEM ba } \\
\text { s in STE } \\
\text { npares } \mathrm{f} \\
\text { reate de }\end{array}$ & $\begin{array}{l}\text { Shortas } \\
\text { rtin } \\
\text { Ashevi } \\
\text { state } \\
\\
\text { nd Edu } \\
\text { ureate } \\
\text { eas. Us } \\
\text { ably to } \\
\text { in Edu }\end{array}$ & $\begin{array}{r}\text { lucation D } \\
\text { BA } \\
180 \\
134 \\
91 \\
43 \\
85 \\
169 \\
\\
\text { on-Critic } \\
\text { STEM gr } \\
\text { generally } \\
\text { s in Educ } \\
\mathrm{n} \text { but its r }\end{array}$ & $\begin{array}{l}\text { ees Av } \\
\text { STEM } \\
\\
\\
\text { hortag } \\
\text { ate de } \\
\text { ls belo } \\
\text { h - Cri } \\
\text { st arra }\end{array}$ & $\begin{array}{l} \\
3 \\
- \\
- \\
- \\
\\
\text { as, USF } \\
\text { This i } \\
\text { ers in E } \\
\text { Shortag } \\
\text { graduat }\end{array}$ & $\begin{array}{l} \\
\text { enerally } \\
\text { primar } \\
\text { tion - C } \\
\text { duate d } \\
\text { ree offe }\end{array}$ & $\begin{array}{l}\text { Educ } \\
8 \\
2 \\
- \\
- \\
6 \\
1 \\
\text { below } \\
\text { USFSP } \\
\text { l Shorta } \\
\text { es. This } \\
\text { s in criti }\end{array}$ & $\begin{array}{c}\text { MA } \\
\begin{array}{r}\text { MA } \\
- \\
6 \\
- \\
- \\
24\end{array} \\
\text { arrent si } \\
\text { ery limit } \\
\text { accalaur } \\
\text { ue to US } \\
\text { hortage }\end{array}$ & 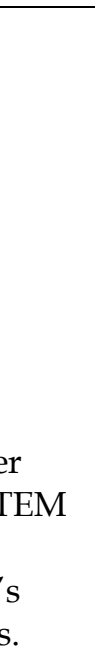 \\
\hline Undergraduate Retention and & & & & & & & & & & \\
\hline $\begin{array}{c}\text { Graduation Rates from Same } \\
\text { Institution }\end{array}$ & Grad & $\begin{array}{l}\text { Still } \\
\text { Enr }\end{array}$ & Grad & $\begin{array}{l}\text { Still } \\
\text { Enr }\end{array}$ & Grad & $\begin{array}{l}\text { Still } \\
\text { Enr }\end{array}$ & Grad & $\begin{array}{l}\text { Still } \\
\text { Enr }\end{array}$ & Grad & $\begin{array}{l}\text { Still } \\
\text { Enr }\end{array}$ \\
\hline Fed.Def.: 6-Yr Rates Full-Time FTICs & $\mathrm{n} / \mathrm{a}$ & $\mathrm{n} / \mathrm{a}$ & $\mathrm{n} / \mathrm{a}$ & $\mathrm{n} / \mathrm{a}$ & $\mathrm{n} / \mathrm{a}$ & $\mathrm{n} / \mathrm{a}$ & 32.88 & 36.94 & 29.09 & 33.33 \\
\hline SUS Def.: 6-Yr Rates - FTICS & $\mathrm{n} / \mathrm{a}$ & $\mathrm{n} / \mathrm{a}$ & $\mathrm{n} / \mathrm{a}$ & $\mathrm{n} / \mathrm{a}$ & $\mathrm{n} / \mathrm{a}$ & $\mathrm{n} / \mathrm{a}$ & $\mathrm{n} / \mathrm{a}$ & $\mathrm{n} / \mathrm{a}$ & $\mathrm{n} / \mathrm{a}$ & $\mathrm{n} / \mathrm{a}$ \\
\hline SUS Def.: 4-Yr Rates - AA Transfers & $\mathrm{n} / \mathrm{a}$ & $\mathrm{n} / \mathrm{a}$ & $\mathrm{n} / \mathrm{a}$ & $\mathrm{n} / \mathrm{a}$ & $\mathrm{n} / \mathrm{a}$ & $\mathrm{n} / \mathrm{a}$ & $\mathrm{n} / \mathrm{a}$ & $\mathrm{n} / \mathrm{a}$ & $\mathrm{n} / \mathrm{a}$ & $\mathrm{n} / \mathrm{a}$ \\
\hline SUS Def.: 5-Yr Rates - Others & $\mathrm{n} / \mathrm{a}$ & $\mathrm{n} / \mathrm{a}$ & $\mathrm{n} / \mathrm{a}$ & $\mathrm{n} / \mathrm{a}$ & $\mathrm{n} / \mathrm{a}$ & $\mathrm{n} / \mathrm{a}$ & $\mathrm{n} / \mathrm{a}$ & $\mathrm{n} / \mathrm{a}$ & $\mathrm{n} / \mathrm{a}$ & $\mathrm{n} / \mathrm{a}$ \\
\hline Comparison with Peers* & $\begin{array}{l}\text { Peer Inst } \\
\text { SUNY at } \\
\text { Universit } \\
\text { Universit } \\
\text { Universit } \\
\text { Universit } \\
\text { Universit }\end{array}$ & $\begin{array}{l}\text { s } \\
\text { ennesse } \\
\text { exas at } \\
\text { I. Caroli } \\
\text { Carolir } \\
\text { Jest Flor }\end{array}$ & $\begin{array}{l}\text { DS Six- } \\
\text { rtin } \\
\text { Ashev } \\
\text { state }\end{array}$ & (Freshn & $\begin{array}{r}\text { Graduc } \\
\text { Gr }\end{array}$ & $\begin{array}{r}\text { Rate ar } \\
\text { tion Ra } \\
79 \\
44 \\
37 \\
54 \\
38 \\
48\end{array}$ & erall Re & $\begin{array}{r}\text { ion Rat } \\
\text { Rete }\end{array}$ & $\begin{array}{l}\text { Rate } \\
90 \% \\
72 \% \\
64 \% \\
82 \% \\
65 \% \\
79 \%\end{array}$ & \\
\hline
\end{tabular}




\begin{tabular}{|c|c|c|c|c|c|}
\hline & \multicolumn{5}{|c|}{$\begin{array}{l}\text { The 6-year graduation rate (Federal Definition) at the six peer institutions ranges from } 37 \% \text { to } 79 \% \text { and the one-year } \\
\text { retention rate ranges from } 64 \% \text { to } 90 \% \text {. At the present time, USFSP is far below these peers. However, it is important to } \\
\text { note that many students start at USFSP and subsequently complete their degrees at another USF location. The only } \\
\text { cohort data available are for years prior to USFSP's separate accreditation (2006). It is expected that the cohorts for } 2006 \\
\text { and forward will show significant improvement in FTIC completions at USFSP. }\end{array}$} \\
\hline Licensure Exam Pass Rates & Year 1 & Year 2 & Year 3 & Year 4 & Year 5 \\
\hline Nursing (2005-06 Through 2009-10) & $\mathrm{n} / \mathrm{a}$ & $\mathrm{n} / \mathrm{a}$ & $\mathrm{n} / \mathrm{a}$ & $\mathrm{n} / \mathrm{a}$ & $\mathrm{n} / \mathrm{a}$ \\
\hline Medicine - Step $1(2006-2010)$ & $\mathrm{n} / \mathrm{a}$ & $\mathrm{n} / \mathrm{a}$ & $\mathrm{n} / \mathrm{a}$ & $\mathrm{n} / \mathrm{a}$ & $\mathrm{n} / \mathrm{a}$ \\
\hline $\begin{array}{c}\text { Medicine - Step } 2 \text { Clinical } \\
\text { Knowledge } \\
\text { (2005-06 Through 2009-10) }\end{array}$ & $\mathrm{n} / \mathrm{a}$ & $\mathrm{n} / \mathrm{a}$ & $\mathrm{n} / \mathrm{a}$ & $\mathrm{n} / \mathrm{a}$ & $\mathrm{n} / \mathrm{a}$ \\
\hline $\begin{array}{l}\text { Medicine - Step } 2 \text { Clinical Skills } \\
(2005-06 \text { Through 2009-10) }\end{array}$ & $\mathrm{n} / \mathrm{a}$ & $\mathrm{n} / \mathrm{a}$ & $\mathrm{n} / \mathrm{a}$ & $\mathrm{n} / \mathrm{a}$ & $\mathrm{n} / \mathrm{a}$ \\
\hline Comparison with Peers* & \multicolumn{5}{|c|}{ There are no nursing or medicine degree programs at USF St. Petersburg } \\
\hline $\begin{array}{c}\text { Academic Research and } \\
\text { Development Expenditures }\end{array}$ & 2004-05 & 2005-06 & 2006-07 & 2007-08 & 2008-09 \\
\hline Federal Only (Thousand \$) & $\mathrm{n} / \mathrm{a}$ & $\mathrm{n} / \mathrm{a}$ & $\mathrm{n} / \mathrm{a}$ & $\mathrm{n} / \mathrm{a}$ & $\mathrm{n} / \mathrm{a}$ \\
\hline Total - All Sources (Thousand \$) & $\mathrm{n} / \mathrm{a}$ & $\mathrm{n} / \mathrm{a}$ & $\mathrm{n} / \mathrm{a}$ & $\mathrm{n} / \mathrm{a}$ & $\mathrm{n} / \mathrm{a}$ \\
\hline Comparison with Peers* & \multicolumn{5}{|c|}{ Data provided only for USF System and USF Tampa } \\
\hline
\end{tabular}




\begin{tabular}{|c|c|c|c|c|c|}
\hline Technology Transfer & 2005 & 2006 & 2007 & 2008 & 2009 \\
\hline Licenses \& Options Executed & $\mathrm{n} / \mathrm{a}$ & $\mathrm{n} / \mathrm{a}$ & $\mathrm{n} / \mathrm{a}$ & $\mathrm{n} / \mathrm{a}$ & $\mathrm{n} / \mathrm{a}$ \\
\hline Licensing Income & $\mathrm{n} / \mathrm{a}$ & $\mathrm{n} / \mathrm{a}$ & $\mathrm{n} / \mathrm{a}$ & $\mathrm{n} / \mathrm{a}$ & $\mathrm{n} / \mathrm{a}$ \\
\hline Comparison with Peers* & \multicolumn{5}{|c|}{ Data provided only for USF System and USF Tampa } \\
\hline \multicolumn{6}{|l|}{$\begin{array}{l}\text { OTHER KEY OUTPUT OR } \\
\text { OUTCOME METRICS }\end{array}$} \\
\hline & & & & & \\
\hline & & & & & \\
\hline & & & & & \\
\hline & & & & & \\
\hline & & & & & \\
\hline & & & & & \\
\hline & & & & & \\
\hline \multicolumn{6}{|l|}{ Comparison with Peers* } \\
\hline \multicolumn{6}{|c|}{$\begin{array}{c}\text { Based on Review of Data Trends on Key Output or Outcome Metrics Identified Here and/or in Annual Report, } \\
\text { Three (3) Areas of Concern/Areas Needing Improvement }\end{array}$} \\
\hline \multicolumn{6}{|c|}{$\begin{array}{l}\text { (1) Graduate Enrollment: USFSP recruits its graduate students primarily from the local community and the nearby region. Historically, the } \\
\text { largest programs have been in education (for in-service teachers) and business (MBA). With the continuing economic difficulties in the } \\
\text { state, and the financial challenges facing school districts that have reduced professional development funding, graduate enrollments have } \\
\text { weakened significantly in Education programs. Business has remained stable. }\end{array}$} \\
\hline \multicolumn{6}{|c|}{$\begin{array}{l}\text { (2) Increased STEM Degree Production: the "New Florida Initiative" envisions that Florida's future lies in growing a "knowledge and } \\
\text { innovation economy" that "is sustained by high-technology, high-wage jobs in the fields of science, technology, engineering and } \\
\text { mathematics (or "STEM")." In order for USFSP to contribute meaningfully to this statewide goal, it must expand its STEM and STEM } \\
\text { education degree offerings. This process has begun with a new BS in Health Sciences, but will need to continue to achieve the New } \\
\text { Florida goals both in overall graduates and in retention and graduation rates. }\end{array}$} \\
\hline
\end{tabular}




\section{UPDATES TO 2010 UNIVERSITY WORK PLAN}

[Please identify briefly any critical changes only to information provided in the 2010 University Work Plan that was not updated in the 2009-2010 Annual Report regarding the institution's strategic plan; institutional mission, vision, and strategic directions for the next five to ten years; current or aspirational peer institutions; windows of opportunity; or unique challenges.]

Reaffirmation: USFSP was initially separately accredited by the Southern Association of Colleges and Schools/Commission on Colleges (SACS/COC) in 2006. SACS/COC requires a full reaffirmation process in the $5^{\text {th }}$ year following initial accreditation. USFSP is in the final stages of this reaffirmation process. The Compliance Certification and on-site visit by the Reaffirmation Committee have been completed successfully. Action on USFSP's reaffirmation will be taken by the SACS/COC in December 2011.

\section{Window of Opportunity:}

STEM Degrees: The "New Florida Initiative" envisions a growing knowledge economy sustained by jobs in the STEM fields, medicine/healthcare, finance, insurance, education and the arts. USFSP plans to increase its degree offerings in STEM as well as STEM education to meet the challenges offered by New Florida. More access to these degrees by Florida resident students is vital and USFSP can offer this access. This increased access will increase degree production in the STEM fields bringing USFSP more in line with its peer institutions, all of which have multiple STEM degrees. For example, USFSP has proposed a BS in Biology which is moving forward to the USF Board of Trustees. In addition, the MS in Middle Grades STEM Education proposed in this Update will combine both robust STEM content with innovative pedagogies designed to retain students in the STEM "pipeline."

USFSP and the USF System: USFSP is an integral part of the evolving USF System. It works closely with the other member institutions to enhance the mission of the USF System. Two institutions currently are separately accredited by the Southern Association of Colleges and Schools (SACS) and have separate IPEDS reporting: USF (in Tampa) and USFSP. USF Sarasota-Manatee expects to receive separate accreditation from SACS in Summer 2011 and USF Polytechnic is pursuing separate accreditation (expected in 2012). All four member institutions are now separately classified by the Carnegie Foundation for the Advancement of Teaching and two, USF (Tampa) and USF St. Petersburg, have the Carnegie elective classification in Community Engagement. 
CAVP Academic Coordination Project (List degree programs recommended for new collaborative or joint delivery model or other corrective action, as well as any degree programs recommended for continuation but for which university and Board staff have not reached agreement on the sufficiency of the rationale.)

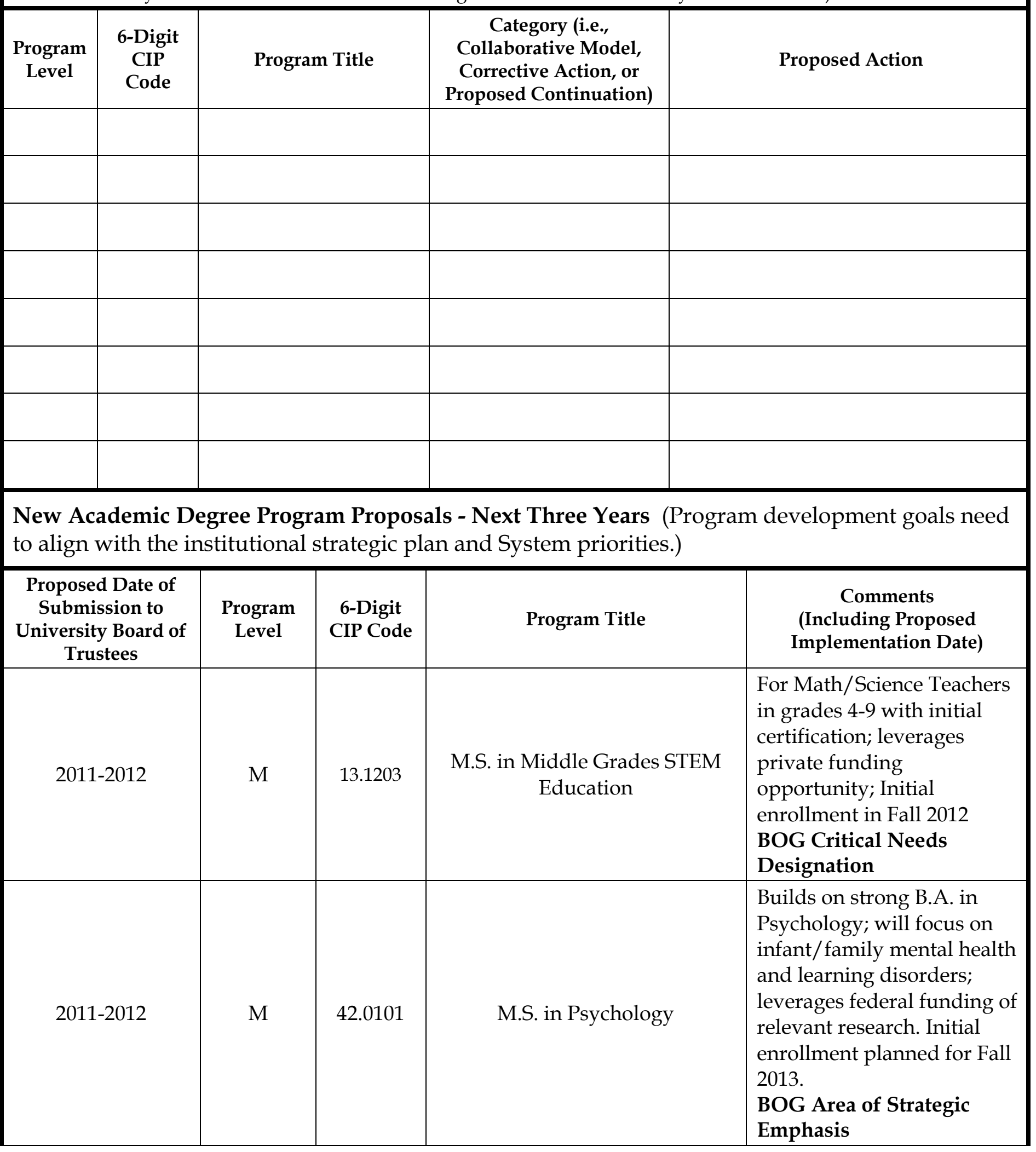




\section{Enrollment Planning}

Please explain briefly any planned changes in enrollment patterns in the next five years, with rationale (e.g., more emphasis on enrolling FCS AA transfers; enrollment of more out-of-state students; enrollment of more FTICs as the institution builds out a more residential experience for undergraduates; maintain undergraduate enrollment with more growth at graduate level to align with institutional mission; plan to maintain current enrollment with more emphasis on improving graduation rates; etc.).

USFSP has projected very modest enrollment growth reflecting the following rationale and assumptions:

- Decreasing absolute numbers of high school students but projected increases in graduation rates from Florida high schools.

- Increased participation of college students in on-line education. A recent study by the SREB has revealed that all of the FTE growth at Florida SUS members in the previous year was accounted for by increased on-line participation.

- Increased FTIC enrollments as USFSP adds residential capacity in 2012-2013.

- Improved graduation rates due to investments in advising, academic support, and better degree progression (Quality Enhancement Plan)

1. Annual FTE enrollment plans by level, site, and residency for tuition purposes in the format provided in the template on the next pages.

2. These are only to include fundable FTE enrollments. So, for example, out-of-state profile admits should not be included in the out-of-state data.

3. Remember that Pharm.D., Law, and other Professional Doctorates (per the recently changed IPEDS definitions) should be counted as Grad II enrollments.

4. An explanation of over-enrollment is required for any level in which the 2010-11 funded enrollment plan lagged actual 2010-11 enrollment by more than 5\% (Section 1011.90, F.S.).

USF St. Petersburg Fundable FTE 2010-2011 Funded Year

\begin{tabular}{|l|ccc|c|c|c|}
\cline { 2 - 7 } \multicolumn{1}{c|}{} & $\begin{array}{c}\text { Summer } \\
2010\end{array}$ & \begin{tabular}{c} 
Fall \\
\multicolumn{1}{c|}{2010}
\end{tabular} & $\begin{array}{c}\text { Spring } \\
2011^{*}\end{array}$ & Actual & Funded** & $\begin{array}{c}\text { \% Actual } \\
\text { over } \\
\text { Funded }\end{array}$ \\
\hline Lower Level & 140.65 & 418.23 & 357.49 & 916.37 & 657 & $28 \%$ \\
Upper Level & 301.92 & 650.72 & 669.17 & 1621.81 & 1486 & $8 \%$ \\
Grad & 70.6 & 94.71 & 85.34 & 250.65 & 227 & $9 \%$ \\
Grad II & N/A & N/A & N/A & N/A & N/A & N/A \\
\hline Total University & 513.29 & 1163.72 & 1112.56 & 2789.57 & 2370 & $15 \%$ \\
\hline
\end{tabular}

USF St. Petersburg Enrollment \& Marketing Services

*Final report unavailable for Spring 2011 term, preliminary report utilized.

**Source: USF St. Petersburg SUS Workplan, 2010

24-Mar-11

USFSP exceeded its 2010 Enrollment Plan in all categories. This was due to a number of factors including a revamped admissions process and team; a change in transfer admissions requirements to be more in line with other SUS institutions; and more focus on graduate student admissions outreach services. 


\begin{tabular}{|c|c|c|c|c|c|c|c|c|}
\hline \multicolumn{9}{|c|}{$\begin{array}{l}\text { Enrollment Plan Proposal - All State-Fundable FTE Enrollments } \\
\text { (Except Medical/Dental/Veterinary Enrollments) }\end{array}$} \\
\hline $\begin{array}{l}\text { For entire } \\
\text { institution }\end{array}$ & Funded & Estimated & Funded & Estimated & Estimated & Estimated & Estimated & \multirow{2}{*}{$\begin{array}{c}\text { 5-Year } \\
\text { Projected } \\
\text { Average } \\
\text { Annual } \\
\text { Growth } \\
\text { Rate }\end{array}$} \\
\hline FTE & $2010-11$ & $2010-11$ & 2011-12 & 2011-12 & 2012-13 & 2014-15 & 2016-17 & \\
\hline $\begin{array}{c}\text { FL } \\
\text { Resident } \\
\text { Lower }\end{array}$ & 657 & 825 & 657 & 837 & 850 & 876 & 902 & $1.5 \%$ \\
\hline $\begin{array}{c}\text { FL } \\
\text { Resident } \\
\text { Upper }\end{array}$ & 1486 & 1613 & 1486 & 1637 & 1662 & 1712 & 1764 & $1.5 \%$ \\
\hline $\begin{array}{c}\text { FL } \\
\text { Resident } \\
\text { Grad I }\end{array}$ & 227 & 258 & 227 & 262 & 266 & 274 & 282 & $1.5 \%$ \\
\hline $\begin{array}{c}\text { FL } \\
\text { Resident } \\
\text { Grad II }\end{array}$ & 0 & 0 & 0 & 0 & 0 & 0 & 0 & N/A \\
\hline $\begin{array}{l}\text { Total FL } \\
\text { Resident }\end{array}$ & 2370 & 2696 & 2370 & 2736 & 2777 & 2861 & 2948 & $1.5 \%$ \\
\hline $\begin{array}{l}\text { Non-Res. } \\
\text { Lower }\end{array}$ & & 20 & & 21 & 21 & 21 & 22 & $1.5 \%$ \\
\hline $\begin{array}{l}\text { Non-Res. } \\
\text { Upper }\end{array}$ & & 35 & & 36 & 36 & 37 & 38 & $1.5 \%$ \\
\hline $\begin{array}{l}\text { Non-Res. } \\
\text { Grad I }\end{array}$ & & 8 & & 8 & 8 & 8 & 9 & $1.5 \%$ \\
\hline $\begin{array}{l}\text { Non-Res. } \\
\text { Grad II }\end{array}$ & & 0 & & 0 & 0 & 0 & 0 & N/A \\
\hline $\begin{array}{l}\text { Total Non- } \\
\text { Res. }\end{array}$ & & 63 & - & 64 & 65 & 67 & 69 & $1.5 \%$ \\
\hline $\begin{array}{c}\text { Total } \\
\text { Lower }\end{array}$ & & 845 & & 858 & 871 & 897 & 924 & $1.5 \%$ \\
\hline $\begin{array}{l}\text { Total } \\
\text { Upper }\end{array}$ & & 1648 & & 1673 & 1698 & 1749 & 1802 & $1.5 \%$ \\
\hline $\begin{array}{c}\text { Total Grad } \\
\text { I }\end{array}$ & & 266 & & 270 & 274 & 282 & 291 & $1.5 \%$ \\
\hline $\begin{array}{l}\text { Total Grad } \\
\text { II }\end{array}$ & & 0 & & 0 & 0 & 0 & 0 & N/A \\
\hline Total FTE & & 2759 & - & 2801 & 2843 & 2928 & 3017 & $1.5 \%$ \\
\hline
\end{tabular}




\begin{tabular}{|c|c|c|c|c|c|c|c|c|}
\hline \multicolumn{9}{|c|}{ Enrollment Plan Proposal - Medical/Dental/Veterinary State-Fundable Enrollments } \\
\hline $\begin{array}{l}\text { For entire } \\
\text { institution }\end{array}$ & Funded & Estimated & Funded & Estimated & Estimated & Estimated & Estimated & \multirow{2}{*}{$\begin{array}{c}\text { 5-Year } \\
\text { Projected } \\
\text { Average } \\
\text { Annual } \\
\text { Growth } \\
\text { Rate }\end{array}$} \\
\hline Headcount & 2010-11 & $2010-11$ & 2011-12 & 2011-12 & $2012-13$ & 2014-15 & 2016-17 & \\
\hline $\begin{array}{c}\text { FL Resident } \\
\text { Medical } \\
\text { Headcount }\end{array}$ & 0 & 0 & 0 & 0 & 0 & 0 & 0 & 0 \\
\hline $\begin{array}{c}\text { Non-Res. } \\
\text { Medical } \\
\text { Headcount }\end{array}$ & & 0 & & 0 & 0 & 0 & 0 & 0 \\
\hline $\begin{array}{l}\text { Total Medical } \\
\text { Headcount }\end{array}$ & 0 & 0 & 0 & 0 & 0 & 0 & 0 & 0 \\
\hline $\begin{array}{c}\text { FL Resident } \\
\text { Dentistry } \\
\text { Headcount }\end{array}$ & 0 & 0 & 0 & 0 & 0 & 0 & 0 & 0 \\
\hline $\begin{array}{c}\text { Non-Res. } \\
\text { Dentistry } \\
\text { Headcount }\end{array}$ & & 0 & & 0 & 0 & 0 & 0 & 0 \\
\hline $\begin{array}{c}\text { Total } \\
\text { Dentistry } \\
\text { Headcount }\end{array}$ & 0 & 0 & 0 & 0 & 0 & 0 & 0 & 0 \\
\hline $\begin{array}{c}\text { FL Resident } \\
\text { Veterinary } \\
\text { Headcount }\end{array}$ & 0 & 0 & 0 & 0 & 0 & 0 & 0 & 0 \\
\hline $\begin{array}{l}\text { Non-Res. } \\
\text { Veterinary } \\
\text { Headcount } \\
\end{array}$ & & 0 & & 0 & 0 & 0 & 0 & 0 \\
\hline $\begin{array}{c}\text { Total } \\
\text { Veterinary } \\
\text { Headcount }\end{array}$ & 0 & 0 & 0 & 0 & 0 & 0 & 0 & 0 \\
\hline
\end{tabular}

[This medical headcount is MD-only, not all HSC enrollments.] 
For each distinct physical location (main, branch, site, regional campus) that has or is planned to have more than 150 FTE State-fundable enrollments

SITE: USF St. Petersburg

\begin{tabular}{|c|c|c|c|c|c|c|}
\hline & Estimated & Estimated & Estimated & Estimated & Estimated & 5-Year \\
\hline FTE & 2010-11 & 2011-12 & 2012-13 & 2014-15 & 2016-17 & $\begin{array}{c}\text { Average } \\
\text { Annual } \\
\text { Growth Rate }\end{array}$ \\
\hline Lower & 845 & 858 & 871 & 897 & 924 & $1.5 \%$ \\
\hline Upper & 1648 & 1673 & 1698 & 1749 & 1802 & $1.5 \%$ \\
\hline Grad I & 266 & 270 & 274 & 282 & 291 & $1.5 \%$ \\
\hline Grad II & 0 & 0 & 0 & 0 & 0 & $0 \%$ \\
\hline Total & 2759 & 2801 & 2843 & 2928 & 3017 & $1.5 \%$ \\
\hline \multicolumn{7}{|l|}{ SITE: } \\
\hline & Estimated & Estimated & Estimated & Estimated & Estimated & \multirow{2}{*}{$\begin{array}{c}\text { 5-Year } \\
\text { Projected } \\
\text { Average } \\
\text { Annual } \\
\text { Growth Rate } \\
\end{array}$} \\
\hline FTE & 2010-11 & 2011-12 & 2012-13 & 2014-15 & 2016-17 & \\
\hline Lower & & & & & & \\
\hline Upper & & & & & & \\
\hline Grad I & & & & & & \\
\hline Grad II & & & & & & \\
\hline \multicolumn{7}{|l|}{ Total } \\
\hline \multicolumn{7}{|l|}{ SITE: } \\
\hline & Estimated & Estimated & Estimated & Estimated & Estimated & \multirow{2}{*}{$\begin{array}{c}\text { 5-Year } \\
\text { Projected } \\
\text { Average } \\
\text { Annual } \\
\text { Growth Rate } \\
\end{array}$} \\
\hline FTE & $2010-11$ & 2011-12 & 2012-13 & 2014-15 & 2016-17 & \\
\hline Lower & & & & & & \\
\hline Upper & & & & & & \\
\hline Grad I & & & & & & \\
\hline Grad II & & & & & & \\
\hline Total & & & & & & \\
\hline
\end{tabular}


For the sum of the remaining physical locations with fewer than 150 current or planned State-fundable FTE enrollments.

SITE: Pasco-Hernando Community College

\begin{tabular}{|c|c|c|c|c|c|c|}
\hline & Estimated & Estimated & Estimated & Estimated & Estimated & 5-Year \\
\hline FTE & $2010-11$ & 2011-12 & $2012-13$ & 2014-15 & 2016-17 & $\begin{array}{c}\text { Average } \\
\text { Annual } \\
\text { Growth Rate }\end{array}$ \\
\hline Lower & 0 & 0 & 0 & 0 & 0 & 0 \\
\hline Upper & 70 & 71 & 72 & 73 & 74 & $1 \%$ \\
\hline Grad I & 1 & 1 & 1 & 1 & 1 & $1 \%$ \\
\hline Grad II & 0 & 0 & 0 & 0 & 0 & 0 \\
\hline Total & 71 & 72 & 73 & 74 & 75 & $1 \%$ \\
\hline
\end{tabular}

For the sum of current or planned State-fundable FTE enrollments not served at a physical location.

SITE: VIRTUAL INSTRUCTION / DISTANCE LEARNING

\begin{tabular}{|cc|c|c|c|c|c|}
\hline & Estimated & Estimated & Estimated & Estimated & Estimated & $\begin{array}{c}\text { 5-Year } \\
\text { Projected } \\
\text { Average } \\
\text { Annual } \\
\text { Growth Rate }\end{array}$ \\
\hline Lower & $\mathbf{2 0 1 0 - 1 1}$ & $\mathbf{2 0 1 1 - 1 2}$ & $\mathbf{2 0 1 2 - 1 3}$ & $\mathbf{2 0 1 4 - 1 5}$ & $\mathbf{2 0 1 6 - 1 7}$ & $3.0 \%$ \\
\hline Upper & 161 & 166 & 172 & 181 & 193 & $2.0 \%$ \\
\hline Grad I & 455 & 464 & 473 & 493 & 513 & $3.0 \%$ \\
\hline Grad II & 37 & 38 & 39 & 41 & 44 & 0 \\
\hline Total & 0 & 0 & 0 & 0 & 0 & $2.3 \%$ \\
\hline
\end{tabular}

Note: Virtual Instruction/Distance Learning FTE are included in the summary data for USF St. Petersburg. 
Primary Institutional Goals/Metrics for the Next One to Three Years (In the context of the institutional strategic plan and vision, as well as System priorities, present three (3) to five (5) goals on which university effort will be focused in the next one to three years. Describe each goal, including whether the goal is new or continuing, the strategies for achieving that goal, the timeline and metrics by which success will be measured, expected outcomes, and assumptions, including financial, upon which the projected outcomes are predicated.) Each university is asked to include one goal associated with improved baccalaureate retention and graduation (e.g., improved first-year retention; reduce attainment gaps for underrepresented groups; improve graduation rates for AA transfers; etc.).

\section{Institutional Goal [Indicate whether NEW or CONTINUING]}

\#1 (Required) - IMPROVE BACCALAUREATE RETENTION AND GRADUATION (CONTINUING).

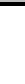

Strategy: Enhance support for student learning through implementation of the institution's Quality Enhancement Plan (QEP) focused on improving student performance in gateway mathematics and statistics courses. This will include enhanced support for student achievement through increased staffing for academic success center and math courses; increase communication and planning between orientation, advising and academic programs; enhance the student experience through refinement of undergraduate and graduate program offerings. Enhance support services for TRIO/SSS students (low income/first generation) as well as for Pell Grant recipient population (about $40 \%$ of baccalaureate population).
\end{abstract} ]

\section{Metric(s)/Timeline/Expected Outcomes}

Metrics: Retention rate year to year; $4 / 5 / 6$ year graduation rate; ratio of academic advisors to students; number of D/F/W grades in key gateway courses (College Algebra, Finite Mathematics, Elementary Statistics); number of students accepted to/enrolled in post-

baccalaureate training or employed within 1 year of graduation; increased student satisfaction with academic advising and academic success (tutoring) center.

Timeline for Actions To Be Taken in FY2011-12: Initial implementation of USFSP's Quality Enhancement Plan focused on quantitative literacy; use of incremental Tuition Differential funding to hire one additional mathematics faculty member and additional staff/tutors for the Academic Success Center, further refinement of orientation programs for FTIC and transfer students to integrate more fully academic and social elements of college life.

Expected Outcomes: 6-year graduation rate for FTIC increases within 4 years; 4 -year graduation rate for AA transfers rises by at least $4 \%$ within 3 years; D/F/W rate falls by $20 \%$ in College Algebra within 2 years; students employed or accepted/enrolled in post-baccalaureate training increases within 4 years; student satisfaction with academic advising/tutoring serviced and overall 


\begin{tabular}{|c|c|c|c|c|c|c|c|c|c|}
\hline & & & & & & \multicolumn{4}{|c|}{$\begin{array}{l}\text { experience as measured by the NSSE increases } \\
\text { within } 3 \text { years. } \\
\text { Assumptions: Funding will be provided for the } \\
\text { Director and co-director of the QEP, for } \\
\text { administrative support staff for the Academic } \\
\text { Success Center, for one additional faculty member } \\
\text { in mathematics, and for enhanced support for } \\
\text { tutors including stronger academic "early } \\
\text { intervention" programs. }\end{array}$} \\
\hline \multicolumn{4}{|c|}{ Proposed Funding Source: $2011-12$} & \multicolumn{6}{|c|}{ Proposed Funding Source: 2012-13 } \\
\hline $\begin{array}{l}\text { State/ Tuition } \\
\text { Revenue (est.) }\end{array}$ & $\begin{array}{c}\text { Other } \\
\text { (Identify } \\
\text { Revenue } \\
\text { Source - } \\
\text { e.g., Private) } \\
\end{array}$ & $\begin{array}{l}\text { Undergrad. } \\
\text { Tuition } \\
\text { Differential } \\
\text { Revenue } \\
\text { (est.) }\end{array}$ & $\begin{array}{l}\text { Total from } \\
2011-12\end{array}$ & $\begin{array}{l}\text { Undergrad. } \\
\text { Tuition } \\
\text { Differential } \\
\text { Revenue (est.) }\end{array}$ & $\begin{array}{c}\text { Legislative } \\
\text { Budget } \\
\text { Request } \\
\text { (State Funds) }\end{array}$ & $\begin{array}{l}\text { State/ } \\
\text { Tuition } \\
\text { Revenue } \\
\text { (est.) }\end{array}$ & $\begin{array}{c}\text { Other } \\
\text { (Identify } \\
\text { Revenue } \\
\text { Source - } \\
\text { e.g., } \\
\text { Private) } \\
\end{array}$ & $\begin{array}{c}\text { Total from } \\
\text { 2012-13 }\end{array}$ & $\begin{array}{l}2012-13 \text { to } \\
2016-17 \\
\text { PECO/ } \\
\text { Courtelis } \\
\text { Request }\end{array}$ \\
\hline 97,750 & 0 & 140,600 & 238,350 & 147,630 & 0 & 97,750 & 0 & 245,380 & \\
\hline \multicolumn{3}{|c|}{$\begin{array}{c}\text { Institutional Goal } \\
\text { [Indicate whether NEW or CONTINUING] }\end{array}$} & \multicolumn{3}{|c|}{ Implementation Strategies } & \multicolumn{4}{|c|}{ Expected Outcomes/Metric(s)/Timeline } \\
\hline \multicolumn{3}{|c|}{$\begin{array}{l}\text { \#2 (Required) - : Increase faculty and } \\
\text { student research and creative activities } \\
\text { (CONTINUING). }\end{array}$} & \multicolumn{3}{|c|}{$\begin{array}{l}\text { Strategy: Expand knowledge of and } \\
\text { opportunities for research within the } \\
\text { faculty, particularly for new and pre- } \\
\text { tenure faculty; increase involvement of } \\
\text { undergraduates in research and creative } \\
\text { activity with faculty; expand research and } \\
\text { scholarly collaborations with community } \\
\text { partners (federal/state/local government, } \\
\text { private sector); enhance institutional } \\
\text { infrastructure for research and sponsored } \\
\text { programs administration; enhance } \\
\text { institutional support for graduate } \\
\text { students, particularly graduate research } \\
\text { assistants. }\end{array}$} & \multicolumn{4}{|c|}{$\begin{array}{l}\text { Metrics: Total amount of externally funded } \\
\text { research annually; number of large awards (over } \\
\$ 100,000 \text { ) annually; number of proposals written; } \\
\text { percentage of proposals awarded; number of } \\
\text { publications in peer-refereed } \\
\text { journals/books/monographs; number of faculty } \\
\text { publications with student } \\
\text { (graduate/ undergraduate) co-authors; number of } \\
\text { student presentations at } \\
\text { local/regional/national/international } \\
\text { conferences; number of proposals/awards } \\
\text { and/or publications with non-USFSP co- } \\
\text { authors/co-investigators. } \\
\text { Timeline for Actions to Be Taken in FY2011-12: } \\
\text { Increased training in research administration for } \\
\text { faculty and unit staff; establishment of annual } \\
\text { calendar of research-related events and activities; }\end{array}$} \\
\hline
\end{tabular}




\begin{tabular}{|c|c|c|c|c|c|c|c|c|c|}
\hline & & & & & & \multicolumn{4}{|c|}{$\begin{array}{l}\text { enhanced reporting to enable at least quarterly } \\
\text { updates of research funding received; } \\
\text { development of database for student research } \\
\text { (graduate and undergraduate) to identify student } \\
\text { learning gains as a result of research experiences; } \\
\text { strengthen electronic proposal submission process } \\
\text { Expected Outcomes: Number of proposals } \\
\text { written to external sponsors will increase by 10\% } \\
\text { over two years; total dollar value of all awards } \\
\text { will increase by } 5 \text { percent over three years; } \\
\text { number of peer-refereed publications (accepted or } \\
\text { in press) will increase by } 5 \text { percent over two years; } \\
\text { number of publications with student co-authors } \\
\text { will increase by } 10 \% \text { over three years; number of } \\
\text { student presentations at local/regional/national } \\
\text { /international conferences will increase by 15\% } \\
\text { over } 3 \text { years; retention and graduation rates will } \\
\text { improve as undergraduate research has been } \\
\text { shown to increase these outcome measures. } \\
\text { Assumptions: Funding for undergraduate } \\
\text { research program with faculty including summer } \\
\text { and academic year; development and approval of } \\
\text { capstone or research courses for students in } \\
\text { selected majors. }\end{array}$} \\
\hline \multicolumn{4}{|c|}{ Proposed Funding Source: $2011-12$} & \multicolumn{6}{|c|}{ Proposed Funding Source: 2012-13 } \\
\hline $\begin{array}{l}\text { State/ Tuition } \\
\text { Revenue (est.) }\end{array}$ & $\begin{array}{c}\text { Other } \\
\text { (Identify } \\
\text { Revenue } \\
\text { Source - } \\
\text { e.g., Private) }\end{array}$ & $\begin{array}{l}\text { Undergrad. } \\
\text { Tuition } \\
\text { Differential } \\
\text { Revenue } \\
\text { (est.) }\end{array}$ & $\begin{array}{l}\text { Total from } \\
2011-12\end{array}$ & $\begin{array}{c}\text { Undergrad } \\
\text { Tuition } \\
\text { Differential } \\
\text { Revenue (est.) }\end{array}$ & $\begin{array}{c}\text { Legislative } \\
\text { Budget } \\
\text { Request } \\
\text { (State Funds) }\end{array}$ & $\begin{array}{c}\text { State/ } \\
\text { Tuition } \\
\text { Revenue } \\
\text { (est.) }\end{array}$ & $\begin{array}{c}\text { Other } \\
\text { (Identify } \\
\text { Revenue } \\
\text { Source - } \\
\text { e.g., } \\
\text { Private) } \\
\end{array}$ & $\begin{array}{c}\text { Total from } \\
\text { 2012-13 }\end{array}$ & $\begin{array}{l}2012-13 \text { to } \\
2016-17 \\
\text { PECO/ } \\
\text { Courtelis } \\
\text { Request }\end{array}$ \\
\hline 10,000 & $\begin{array}{l}122,500 \\
\text { Private }\end{array}$ & 0 & 123,500 & 0 & 0 & 10,000 & $\begin{array}{l}122,500 \\
\text { Private }\end{array}$ & 123,500 & \\
\hline \multicolumn{3}{|c|}{$\begin{array}{l}\text { Institutional Goal } \\
\text { [Indicate whether NEW or CONTINUING] }\end{array}$} & \multicolumn{3}{|c|}{ Implementation Strategies } & \multicolumn{4}{|c|}{ Expected Outcomes/Metric(s)/Timeline } \\
\hline
\end{tabular}


\#3 (Required) - Enhance Student Success and overall campus experience by completing construction of the Multipurpose Student Center (MPSC); renovating the former Dali Museum (Harbor Hall); renovating the current Campus Activities Center (CAC) to consolidate student services into this facility and provide space for a Student Health and Wellness Clinic (NEW)
Strategy: Construction of the MPSC underway. The MPSC will encompass a dining facility, additional residential spaces, meeting spaces. When combined with the renovation of the existing Campus Activities Center (CAC), these two facilities will provide much needed space for student services such as the Career Center as well as additional space to accommodate the rapid growth in student organizations. A critically-needed Health and Wellness Clinic is also planned.

Complete the infrastructure improvements needed in Harbor Hall including new roof, information technology, a fire suppression system that meets current codes, and additional renovations for environmental health and safety. Harbor Hall will house academic programs and will provide greater opportunities for academic collaboration.
Proposed Funding Source: 2011-12

\begin{tabular}{|l|c|c|c|}
\hline \multicolumn{4}{|c|}{ Proposed Funding Source: 2011-12 } \\
\hline & Other & Undergrad & \\
State/ Tuition & (Identify & Tuition & Total from \\
Revenue (est.) & Revenue & Differential & $2011-12$ \\
& Source - & Revenue & \\
\hline
\end{tabular}

Metrics: Enhanced student satisfaction through surveys such as the NSSE and CIRP; greater numbers of student organizations and measurement of the impact of these organizations on campus life and the community (through surveys of entities such as the St. Petersburg Downtown Partnership); enhanced revenues from residential occupancy and dining; enhanced academic collaborations.

\section{Timeline for Actions to be Taken in 2011-2012:}

Maintain construction schedule for completion of MPSC by August of 2012. Initiate CAC

Renovation in October of 2011. Complete infrastructure improvements for Harbor Hall so that academic programs can be housed prior to Fall 2011 semester. Complete space renovation for a Student Health Clinic by July 1, 2012.

Expected Outcomes: In 2011-2012 USFSP will complete these projects to house students for the 2012-2013 academic year. At completion, the campus residential population is expected to rise by $25-35 \%$. The institution expects to experience a significant increase in auxillary revenues through expanded food service and facility rentals.

\section{Assumptions:}

Construction will proceed on schedule and on budget for the MPSC and renovation of the CAC, and the creation of the Student Health and Wellness Clinic. All required permitting for Harbor Hall will be acquired in a timely way. Cost estimates for all projects will be within budgetary limits.

Proposed Funding Source: 2012-13

\begin{tabular}{c|c|c|c|c|c} 
Undergrad & Legislative & State/ & Other & & $2012-13$ to \\
Tuition & Budget & Tuition & (Identify & Total from & $2016-17$ \\
Differential & Request & Revenue & Revenue & $2012-13$ & PECO/ \\
Revenue (est.) & (State Funds) & (est.) & Source - & & Courtelis \\
\hline
\end{tabular}




\begin{tabular}{|c|c|c|c|c|c|c|c|c|c|}
\hline & \begin{tabular}{|l|} 
e.g., Private) \\
\end{tabular} & (est.) & & & & & $\begin{array}{c}\text { e.g., } \\
\text { Private) }\end{array}$ & & Request \\
\hline $2,963,299$ & $\begin{array}{r}1,450,000 \\
\text { student fees }\end{array}$ & 0 & $4,413,299$ & 0 & 0 & $2,000,000$ & $\begin{array}{r}1,450,000 \\
\text { student fees }\end{array}$ & $3,450,000$ & 0 \\
\hline \multicolumn{3}{|c|}{$\begin{array}{l}\text { \#4 (Optional) - Support faculty and staff } \\
\text { related to undergraduate education and } \\
\text { enhance undergraduate degree programs } \\
\text { through new Tuition Differential funding. } \\
\text { (NEW) }\end{array}$} & \multicolumn{3}{|c|}{$\begin{array}{l}\text { Strategy: Tuition differential revenue will } \\
\text { be used to support new faculty who will } \\
\text { provide instruction in undergraduate } \\
\text { degree programs, specifically, the BS in } \\
\text { Health Sciences, the BS in } \\
\text { Entrepreneurship, the BA in Psychology } \\
\text { (most popular major), BA in History and } \\
\text { other high productivity programs in order } \\
\text { to maintain existing student/faculty ratio } \\
\text { and improve graduation rates. In } \\
\text { addition, tuition differential funding will } \\
\text { support academic advisors and advising } \\
\text { office staff to reduce advisor/student ratio } \\
\text { and provide enhanced academic advising } \\
\text { services for undergraduate students } \\
\text { (which will improve retention and } \\
\text { graduation rates). } \\
\text { (This strategy is in addition to the Strategy } \\
\text { supporting Goal } 1 \text { which also addresses } \\
\text { enhanced student retention) }\end{array}$} & \multicolumn{4}{|c|}{$\begin{array}{l}\text { Metrics: Increase in 2/3/4/5/6-year graduation } \\
\text { rates for FTIC and AA transfers from } 2005 \\
\text { baseline; maintain student/ faculty ratio from } 2008 \\
\text { baseline; improve student/advisor ratio from } 2008 \\
\text { baseline; maintain or increase undergraduate } \mathrm{SCH} \\
\text { production from } 2009 \text { baseline. } \\
\text { Timeline for Actions to be Taken in 2011-2012: } \\
\text { Continue current commitments to faculty and staff } \\
\text { already supported on Tuition Differential funding; } \\
\text { use increased Tuition Differential revenue to } \\
\text { support new faculty in high productivity } \\
\text { programs to maintain or increase access to courses } \\
\text { necessary for timely degree progression. } \\
\text { Expected Outcomes: Increased graduation rates; } \\
\text { students will be able to enroll in courses on the } \\
\text { critical path to graduation without delay; students } \\
\text { will receive timely academic advising to support } \\
\text { timely progress to degree. } \\
\text { Assumptions: Tuition increase will be } 7 \% \text { for all } \\
\text { undergraduate courses and will be added to } \\
\text { existing tuition differential funding. }\end{array}$} \\
\hline \multicolumn{4}{|c|}{ Proposed Funding Source: $2011-12$} & \multicolumn{6}{|c|}{ Proposed Funding Source: $2012-13$} \\
\hline $\begin{array}{l}\text { State/ Tuition } \\
\text { Revenue (est.) }\end{array}$ & $\begin{array}{l}\text { Other } \\
\text { (Identify } \\
\text { Revenue } \\
\text { Source - e.g., } \\
\text { Private) }\end{array}$ & $\begin{array}{l}\text { Undergrad } \\
\text { Tuition } \\
\text { Differential } \\
\text { Revenue } \\
\text { (est.) }\end{array}$ & $\begin{array}{c}\text { Total from } \\
\text { 2011-12 }\end{array}$ & $\begin{array}{c}\text { Undergrad } \\
\text { Tuition } \\
\text { Differential } \\
\text { Revenue (est.) }\end{array}$ & $\begin{array}{c}\text { Legislative } \\
\text { Budget } \\
\text { Request } \\
\text { (State Funds) }\end{array}$ & $\begin{array}{c}\text { State/ } \\
\text { Tuition } \\
\text { Revenue } \\
\text { (est.) }\end{array}$ & $\begin{array}{l}\text { Other } \\
\text { (Identify } \\
\text { Revenue } \\
\text { Source - } \\
\text { e.g., } \\
\text { Private) } \\
\end{array}$ & $\begin{array}{c}\text { Total from } \\
2012-13\end{array}$ & $\begin{array}{l}2012-13 \text { to } \\
2016-17 \\
\text { PECO/ } \\
\text { Courtelis } \\
\text { Request }\end{array}$ \\
\hline 0 & 0 & $1,881,304$ & $1,881,304$ & $1,975,369$ & 0 & 0 & 0 & $1,975,369$ & 0 \\
\hline
\end{tabular}




\begin{tabular}{|c|c|c|c|c|c|c|c|c|c|c|}
\hline \multicolumn{11}{|c|}{ SUMMARY OF PROPOSED FUNDING FOR PRIMARY GOALS } \\
\hline \multicolumn{5}{|c|}{ Proposed Funding Source: $2011-12$} & \multicolumn{6}{|c|}{ Proposed Funding Source: $2012-13$} \\
\hline Goal \# & $\begin{array}{c}\text { State/ } \\
\text { Tuition } \\
\text { Revenue } \\
\text { (est.) }\end{array}$ & $\begin{array}{c}\text { Other } \\
\text { (Identify } \\
\text { Revenue } \\
\text { Source - } \\
\text { e.g., } \\
\text { Private) }\end{array}$ & $\begin{array}{c}\text { Undergrad } \\
\text { Tuition } \\
\text { Differential } \\
\text { Revenue } \\
\text { (est.) }\end{array}$ & $\begin{array}{c}\text { Total from } \\
2011-12\end{array}$ & $\begin{array}{l}\text { Undergrad } \\
\text { Tuition } \\
\text { Differential } \\
\text { Revenue } \\
\text { (est.) }\end{array}$ & $\begin{array}{c}\text { Legislative } \\
\text { Budget Request } \\
\text { (State Funds) }\end{array}$ & $\begin{array}{c}\text { State/ } \\
\text { Tuition } \\
\text { Revenue } \\
\text { (est.) }\end{array}$ & $\begin{array}{c}\text { Other } \\
\text { (Identify } \\
\text { Revenue } \\
\text { Source - } \\
\text { e.g., } \\
\text { Private) }\end{array}$ & $\begin{array}{c}\text { Total } \\
\text { from } \\
2012-13\end{array}$ & $\begin{array}{l}2012-13 \text { to } \\
2016-17 \\
\text { PECO/ } \\
\text { Courtelis } \\
\text { Request }\end{array}$ \\
\hline 1 & 97,750 & 0 & 140,600 & 238,350 & 147,630 & 0 & 97,750 & 0 & 245,380 & 0 \\
\hline 2 & 10,000 & $\begin{array}{l}122,500 \\
\text { Private }\end{array}$ & 0 & 123,500 & 0 & 0 & 10,000 & $\begin{array}{l}122,500 \\
\text { Private }\end{array}$ & 123,500 & 0 \\
\hline 3 & 2,963,299 & $\begin{array}{r}1,450,000 \\
\text { student fees }\end{array}$ & 0 & $4,413,299$ & 0 & 0 & $2,000,000$ & $\begin{array}{r}1,450,000 \\
\text { student } \\
\text { fees }\end{array}$ & $3,450,000$ & 0 \\
\hline $\begin{array}{c}\mathbf{4} \\
\text { optional } \\
\end{array}$ & 0 & 0 & $1,881,304$ & $1,881,304$ & $1,975,369$ & 0 & 0 & 0 & $1,975,369$ & 0 \\
\hline $\begin{array}{c}5 \\
\text { optional } \\
\end{array}$ & & & & & & & & & & \\
\hline Total & $3,071,049$ & $1,572,500$ & $2,021,904$ & $6,656,453$ & $2,122,999$ & 0 & $2,107,750$ & $1,462,500$ & $5,794,249$ & 0 \\
\hline
\end{tabular}




\section{0 - 2011 Tuition Differential Update}

Provide the following information for the 2010-2011 Academic Year.

\section{0-2011 - 70\% Initiatives (List the initiatives}

provided in the 2010-11 tuition differential request.)

Hiring of additional advisor and staff for academic advising to enable reduction of advisor:student ratio

Hiring of two new faculty members for health sciences

Technology for Registrar's office to enhance student success

Hiring of additional staff for Academic Success

Center

Total Number of Faculty Hired or Retained (funded by tuition differential):

Total Number of Advisors Hired or Retained (funded by tuition differential):

Total Number of Course Sections Added or Saved (funded by tuition differential):

2010-2011 - 30\% Initiatives (list the initiatives

provided in the 2010-11 tuition differential request)

Managed at the USF System Level (See USF System Work Plan)

\section{Additional Information (estimates as of April 30, 2011):}

Unduplicated Count of Students Receiving at least one Tuition Differential-Funded Award:

\$ Mean (per student receiving an award) of Tuition

Differential-Funded Awards:

\$ Minimum (per student receiving an award) of

Tuition Differential-Funded Awards:

\$ Maximum (per student receiving an award) of

Tuition Differential-Funded Awards:

\section{University Update on Each Initiative}

Hiring completed and additional staff are in place

Hiring completed. Faculty will start July 1, 2011

Technology implementation underway. Completion date June 2011

Hiring completed; co-director and administrative staff are in place.

7 (including commitments from previous year)

3 (including commitments from previous year)

16

University Update on Each Initiative 


\section{Fall 2011 Request for an Increased Tuition Differential Fee}

\section{University: University of South Florida St. Petersburg}

\section{Effective Date}

University Board of Trustees Approval Date:

June 8, 2011

Campus or Center Location

Campus or Center Location to which the Tuition

Differential fee will apply (If the entire university, indicate as such):

Undergraduate Course(s)

Course(s). (If the tuition differential fee applies to all university undergraduate courses, indicate as such. If not, also provide a rationale for the differentiation among courses):

\section{Current and Proposed Increase in the Tuition Differential Fee}

Current Undergraduate Tuition Differential per credit hour:

Percentage tuition differential fee increase (calculated as a percentage of the sum of base tuition plus tuition differential):

$\$$ Increase in tuition differential per credit hour:

$\$$ Increase in tuition differential for 30 credit hours:

Projected Differential Revenue Generated and Intended Uses

Incremental differential fee revenue generated in 2011-12 (projected):

Total differential fee revenue generated in 2011-12 (projected):

\begin{tabular}{|r|}
$\$ 849,887$ \\
$\$ 2,021,904$
\end{tabular}


STATE UNIVERSITY SYSTEM OF FLORIDA

Tuition Differential Collections, Expenditures, and Available Balances

University of South Florida - St. Pete

Fiscal Year 2010-2011 and 2011-12

University Tuition Differential

Budget Entity: 48900100 (Educational \& General)

SF/Fund: 2 164xxx (Student and Other Fees Trust Fund)

F/Fund: $164 x x$ (Student and Other Fees Trust Fund)

Estimated Actual ${ }^{*}$

2010-11
Estimated

2011-12

\section{Balance Forward from Prior Periods}

Balance Forward

Less: Prior-Year Encumbrances

Beginning Balance Available:

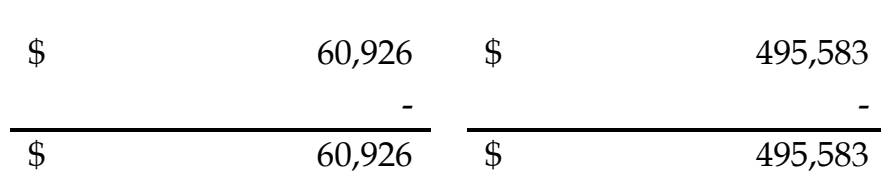

\section{Receipts / Revenues}

Tuition Differential Collections

Interest Revenue - Current Year

Interest Revenue - From Carryforward Balance

Total Receipts / Revenues:

s

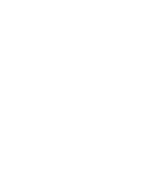

\$ 60,926

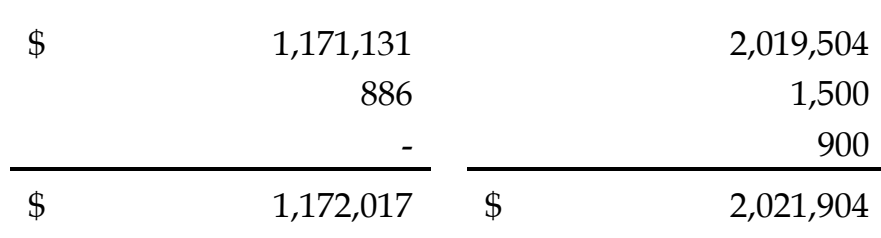

\section{Expenditures}

Salaries \& Benefits

$\$$

308,695

$1,291,053$

Other Personal Services

Expenses

Operating Capital Outlay

Student Financial Assistance

Expended From Carryforward Balance

${ }^{* *}$ Other Category Expenditures

Total Expenditures:

Ending Balance Available:

\begin{tabular}{|c|c|c|c|}
\hline \multicolumn{4}{|c|}{16,400} \\
\hline & - & & \\
\hline & 351,339 & & 605,851 \\
\hline & 60,926 & & 495,583 \\
\hline$\$$ & 737,360 & $\$$ & $2,392,487$ \\
\hline$\$$ & 495,583 & $\$$ & 125,000 \\
\hline
\end{tabular}

*Since the 2010-11 year has not been completed, provide an estimated actual.

**Provide details for "Other Categories" used. 


\section{State University System \\ Florida Board of Governors \\ Instructions for Completing the Revised Operating Budget (OB) Form I}

The OB Form I is designed to capture the data needed to align a university's operating budget issue with the goals and objectives of the State University System (SUS) Strategic Plan and the New Florida Initiative.

Each university should submit one sequential priority list of all budget issues for the university. Any issues unique to a branch campus or a special unit (e.g., IFAS, health science center) should be incorporated into the single university priority list, even if the university decides to separate the base allocation into prorated amounts for each branch campus or special unit.

For each budget issue, please indicate the primary goal from the SUS Strategic Plan that the issue will address, and complete the form according to the instructions provided.

Keep all responses brief. All issues must have been identified in the 2011 University Work Plan submitted to the Board of Governors and must align with the goals and objectives of the SUS Strategic Plan and the New Florida Initiative. 


\section{State University System \\ Education and General \\ 2011-2012 Legislative Operating Budget Issue \\ Form I}

\begin{tabular}{|l|l|}
\hline University: & USF St. Petersburg \\
Work Plan Issue Title: & $\begin{array}{l}\text { Support for Programs in Biology and } \\
\text { Middle Grades STEM Teaching }\end{array}$ \\
\hline Priority Number & $\mathbf{1}$ \\
\hline $\begin{array}{l}\text { Recurring Funds Requested: } \\
\text { Non-Recurring Funds Requested: }\end{array}$ & $\mathbf{\$ 5 4 9 , 9 0 0}$ \\
Total Funds Requested: & $\mathbf{\$ 0}$ \\
& $\mathbf{\$ 5 4 9 , 9 0 0}$ \\
& $\begin{array}{l}\text { (Note: Priority } 1 \text { contains } \$ 699,802 \text { and } \\
\text { Priority X contains } \$ 359,450 \text { for this issue } \\
\text { for a total of } \$ 1,609,101 \text { to complete this } \\
\text { issue) }\end{array}$ \\
\hline
\end{tabular}

Although an issue might address multiple SUS Strategic Plan Goals, please check a single primary goal that this issue will address:

Access to and Production of Degrees (Examples of issues that might support this goal could include services such as outreach programs, new enrollment growth, new elearning opportunities, or increased financial aid to improve student access; academic tracking, advising, tutoring, supplemental instruction, or other support services to improve undergraduate retention and graduation; or enhanced support to develop competitive recruitment packages for recruiting and retaining outstanding graduate and professional students.)

Meeting Statewide Professional and Workforce Needs (Examples of issues that might support this goal could include services that focus on the recruitment and retention of highly qualified students and faculty in disciplines associated with high-skill, high-wage jobs (e.g., STEM fields) or other areas of strategic emphasis in the State University System.)

Building World-Class Academic Programs and Research Capacity (Examples of issues that might support this goal could include focused support for academic programs on the cusp of national or international preeminence; support to achieve specialized accreditation in specific disciplines; new and/or expanded research initiatives built on the core strengths of the institution; or focused support to more quickly move cutting-edge university research to application and/or commercialization.) 
Meeting Community Needs and Fulfilling Unique Institutional

Responsibilities (Examples could include issues important to a region or specific to an institution's mission - e.g., extension services, service learning initiatives, lifelong learning opportunities, community engagement initiatives, or targeted degree programs to meet regional needs.)

\section{Need and Justification:}

A. Identify the need as addressed explicitly in the 2010 University Work Plan, and indicate where this budget issue is referenced in the Plan.

This request addresses a vital need for graduates with STEM degrees and for qualified science and mathematics teachers, particularly in the middle grades. This need is well-documented for Pinellas County, for the broader Tampa Bay region, and for the State of Florida as a whole. The degrees proposed in Biology (BS) and in STEM teaching (MS in Middle Grades Math and Science) were referenced in the 2010 university Work Plan under New Academic Degree Program Proposals - Next Three Years which called for initial enrollment in Fall 2012. They were also referenced in the Work Plan section on Windows of Opportunity/Unique Challenges. USFSP has reviewed these degree program plans and has revised the MS in Middle Grades Math and Science to be an MS in Middle Grades STEM Education which better reflects the inclusion of technology education in the planned degree. The BS in Biology is currently in the approval process by the USF System Board of Trustees.

B. Indicate how this budget issue aligns with the goal selected above from the SUS Strategic Plan.

The State of Florida has identified critical workforce shortages in the science, technology, engineering, mathematics, and medical (STEMM) fields that include Science and Math Teaching. This requested funding will help sustain and enhance USF St. Petersburg's initiative to initiate a new undergraduate degree in Biology and a new Masters degree in Middle Grades STEM Education. This proposal builds on USFSP's existing BS degrees in Environmental Science and Health Sciences and leverages the successful Middle Grades Digital Mathematics initiative (currently a graduate certificate) which has received funding from the Helios and Progress Energy Foundations. The proposal adds staff support for additional capacity in the sciences and in science and math education that will maximize the use of USFSP's Science and 
Technology Building that provides needed teaching classroom and laboratory space.

C. Indicate how this budget issue aligns with the objectives of the New Florida initiative.

This request aligns directly with three of the objectives of the New Florida initiative

1. Focus each university on fulfilling its distinctive mission (research, degree production, solving Florida's problems, or some combination).

USF St. Petersburg is well-positioned to fulfill its distinctive mission as a student-centered, regional comprehensive university oriented to addressing the problems of the region and the state.

3. Focus half of the new funding on targeted degrees, such as Science, Technology, Engineering, and Math programs.

4. Focus half of the new funding on developing a pool of graduates with degrees needed for regional and statewide development (business, nursing, computing, construction, architecture, education, etc.) and create a pool of degreed citizens with creative and analytical thinking skills.

The request speaks directly to these two objectives through production of graduates in the STEM areas (Biology and STEM Education). USFSP has ample empirical evidence that its graduates possess highly developed creative and analytical thinking skills.

\section{Description:}

A. Description of service or program to be provided: (Include whether this is a new or expanded service/program. If expanded, what has been accomplished with the current service/program?)

USF St. Petersburg will initiate a new B.S. in Biology. USFSP already provides most of the courses for this degree but will need additional support for new, advanced courses in areas such as biochemistry, comparative physiology, limnology, and plant molecular biology. The new MS in Middle Grades STEM Education will require additional support for technology-enhanced teaching laboratories. USFSP requests funding to provide graduate student support, capital equipment, and supplies and operating expenses for both degrees, as well as support for undergraduate research. 


\section{B. Description of current university initiatives and resources that will strengthen the provision of this service or program:}

USFSP created a Program of Distinction in Environmental Science, Policy, and Geography (ESPG) in 2003 to expand its science programs and leverage the expertise of its current partners on campus (USGS, FWRI, USF College of Marine Sciences, NOAA). This strategic investment allowed USFSP to hire core science faculty and purchase scientific equipment. A new Science and Technology (S\&T) Building has been funded by the SUS BOG and the building is now operational. This facility provides needed teaching and research laboratory space to expand science and health programming. Moreover, USFSP has now initiated a new B.S. degree program in the Health Sciences aimed at students who will pursue careers or further e study in the paramedical fields. Two new faculty have been hired to support this new degree program through differential tuition funds. In addition, the USFSP College of Education will expand its current programs by initiating a new degree, an M.S. in Middle Grades STEM Education for practicing middle grades math and science teachers. Studies have clearly shown that the middle grades (4-9) represent the greatest source of "leaks" in the STEM pipeline - that is, these grades are where most students abandon their plans to pursue careers or further study in the STEM fields. The USFSP M.S. in Middle Grades STEM will enable USFSP to offer in-depth content and innovative pedagogies in science and mathematics courses and will include technological content knowledge in the middle grades that is necessary to provide future math and science teachers with tools to enhance student performance (and thus retention) in these key grades.

C. Description of outcome(s) anticipated or dashboard indicator(s) to be improved: (Be specific. For example, if this issue focuses on improving retention rates, indicate the current retention rate and the expected increase in the retention rate. In addition, identify the following, if applicable.)

The request for the BS in Biology will address Dashboard Metric \#5 (Degrees Awarded in STEM (Baccalaureate), through awarding of degrees in this area for the first time (see estimated numbers below). This new degree will enable USFSP to be more in line with its peer institutions in STEM degree production.

The request for the MS in Middle Grades STEM Education will have a salient effect on Dashboard Metric \#6 (Degrees Awarded in Specified Education Critical Shortage (Graduate)) by enabling students to pursue advanced education degrees to strengthen math/science/technology teaching at a key point in the STEM pipeline. 
1. Number of Headcount Students receiving services or participating in the program by year, for the next five years:

\begin{tabular}{llr}
\multicolumn{2}{l}{ Biology } & STEM Ed \\
\hline 2012 & 30 & 10 \\
2013 & 35 & 10 \\
2014 & 65 & 15 \\
2015 & 85 & 15 \\
2016 & 100 & 20
\end{tabular}

Number of FTE Students receiving services or participating in the program by year for the next five years:

\begin{tabular}{llc}
\multicolumn{2}{c}{ Biology } & STEM Education \\
\hline 2012 & 22.5 & 10 \\
2013 & 26.25 & 10 \\
2014 & 45 & 12 \\
2015 & 63.75 & 12 \\
2016 & 75 & 15
\end{tabular}

Additional degrees, if any, produced as a result of this initiative: (Indicate the additional number of Bachelor's, Master's, Doctoral, \& Professional degrees to be produced by school year.)

\begin{tabular}{|c|c|c|}
\hline BS in & Biology & MS in STEM Ed \\
\hline 2012 & 0 & 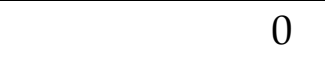 \\
\hline 2013 & 10 & 3 \\
\hline 2014 & 25 & 1 \\
\hline 2015 & 35 & 1 \\
\hline 2016 & 50 & \\
\hline
\end{tabular}

Other outcomes:

\section{Facilities:}

A. Does this issue require an expansion or construction of a facility?

No, a Science and Technology Building project is completed and will support this initiative.

B. If yes, is the project identified on the Capital Improvement List? If so, identify the project, fiscal amount, year requested, and priority number. 


\begin{tabular}{|l|l|l|l|}
\hline 1. & & & \\
\hline 2. & & & \\
\hline
\end{tabular}




\section{State University System \\ Florida Board of Governors \\ Instructions for Completing the Revised Operating Budget (OB) Form I}

The OB Form I is designed to capture the data needed to align a university's operating budget issue with the goals and objectives of the State University System (SUS) Strategic Plan and the New Florida Initiative.

Each university should submit one sequential priority list of all budget issues for the university. Any issues unique to a branch campus or a special unit (e.g., IFAS, health science center) should be incorporated into the single university priority list, even if the university decides to separate the base allocation into prorated amounts for each branch campus or special unit.

For each budget issue, please indicate the primary goal from the SUS Strategic Plan that the issue will address, and complete the form according to the instructions provided.

Keep all responses brief. All issues must have been identified in the 2011 University Work Plan submitted to the Board of Governors and must align with the goals and objectives of the SUS Strategic Plan and the New Florida Initiative. 


\section{State University System \\ Education and General \\ 2011-2012 Legislative Operating Budget Issue \\ Form I}

\begin{tabular}{|l|l|}
\hline University: & USF St. Petersburg \\
Work Plan Issue Title: & $\begin{array}{l}\text { Faculty for Programs in Biology and } \\
\text { Middle Grades STEM Teaching }\end{array}$ \\
\hline Priority Number & 1 \\
Recurring Funds Requested: & $\$ 699,802$ \\
$\begin{array}{l}\text { Non-Recurring Funds Requested: } \\
\text { Total Funds Requested: }\end{array}$ & $\mathbf{\$ 0}$ \\
\hline
\end{tabular}

Although an issue might address multiple SUS Strategic Plan Goals, please check a single primary goal that this issue will address:

Access to and Production of Degrees (Examples of issues that might support this goal could include services such as outreach programs, new enrollment growth, new elearning opportunities, or increased financial aid to improve student access; academic tracking, advising, tutoring, supplemental instruction, or other support services to improve undergraduate retention and graduation; or enhanced support to develop competitive recruitment packages for recruiting and retaining outstanding graduate and professional students.)

Meeting Statewide Professional and Workforce Needs (Examples of issues that might support this goal could include services that focus on the recruitment and retention of highly qualified students and faculty in disciplines associated with high-skill, high-wage jobs (e.g., STEM fields) or other areas of strategic emphasis in the State University System.)

Building World-Class Academic Programs and Research Capacity (Examples of issues that might support this goal could include focused support for academic programs on the cusp of national or international preeminence; support to achieve specialized accreditation in specific disciplines; new and/or expanded research initiatives built on the core strengths of the institution; or focused support to more quickly move cutting-edge university research to application and/or commercialization.)

\section{Meeting Community Needs and Fulfilling Unique Institutional}

Responsibilities (Examples could include issues important to a region or specific to an institution's mission - e.g., extension services, service learning initiatives, lifelong learning opportunities, community engagement initiatives, or targeted degree programs to meet regional needs.) 


\section{Need and Justification:}

A. Identify the need as addressed explicitly in the $\mathbf{2 0 1 0}$ University Work Plan, and indicate where this budget issue is referenced in the Plan.

This request addresses a vital need for graduates with STEM degrees and for qualified science and mathematics teachers, particularly in the middle grades. This need is well-documented for Pinellas County, for the broader Tampa Bay region, and for the State of Florida as a whole. The degrees proposed in Biology (BS) and in STEM teaching (MS in Middle Grades Math and Science) were referenced in the 2010 university Work Plan under New Academic Degree Program Proposals - Next Three Years which called for initial enrollment in Fall 2012. They were also referenced in the Work Plan section on Windows of Opportunity/Unique Challenges. USFSP has reviewed these degree program plans and has revised the MS in Middle Grades Math and Science to be an MS in Middle Grades STEM Education which better reflects the inclusion of technology education in the planned degree. The BS in Biology is currently in the approval process by the USF System Board of Trustees.

B. Indicate how this budget issue aligns with the goal selected above from the SUS Strategic Plan.

The State of Florida has identified critical workforce shortages in the science, technology, engineering, mathematics, and medical (STEMM) fields that include Science and Math Teaching. This requested funding will help sustain and enhance USF St. Petersburg's initiative to initiate a new undergraduate degree in Biology and a new Masters degree in Middle Grades STEM Education. This proposal builds on USFSP's existing BS degrees in Environmental Science and Health Sciences and leverages the successful Middle Grades Digital Mathematics initiative (currently a graduate certificate) which has received funding from the Helios and Progress Energy Foundations. The proposal adds instructional capacity in the sciences and in science and math education that will maximize the use of USFSP's Science and Technology Building that provides needed teaching classroom and laboratory space.

C. Indicate how this budget issue aligns with the objectives of the New Florida initiative. 
This request aligns directly with three of the objectives of the New Florida initiative

1. Focus each university on fulfilling its distinctive mission (research, degree production, solving Florida's problems, or some combination).

USF St. Petersburg is well-positioned to fulfill its distinctive mission as a student-centered, regional comprehensive university oriented to addressing the problems of the region and the state.

3. Focus half of the new funding on targeted degrees, such as Science, Technology, Engineering, and Math programs.

4. Focus half of the new funding on developing a pool of graduates with degrees needed for regional and statewide development (business, nursing, computing, construction, architecture, education, etc.) and create a pool of degreed citizens with creative and analytical thinking skills.

The request speaks directly to these two objectives through production of graduates in the STEM areas (Biology and STEM Education). USFSP has ample empirical evidence that its graduates possess highly developed creative and analytical thinking skills.

\section{Description:}

A. Description of service or program to be provided: (Include whether this is a new or expanded service/program. If expanded, what has been accomplished with the current service/program?)

USF St. Petersburg will initiate a new B.S. in Biology. USFSP already provides most of the courses for this degree but will need additional faculty to support new, advanced courses in areas such as biochemistry, comparative physiology, limnology, and plant molecular biology. . USFSP requests funding to provide instructional salaries and support for approximately 20 course sections per semester in these subjects. The request includes 6 full-time faculty with teaching expertise and research interests in the above areas. For the new M.S. in Middle Grades STEM Education, the requested funding will provide three full-time faculty, one in math education, one in science education, and one in technology education.

\section{B. Description of current university initiatives and resources that will strengthen the provision of this service or program:}

USFSP created a Program of Distinction in Environmental Science, Policy, and Geography (ESPG) in 2003 to expand its science programs and leverage the expertise of its current partners on campus (USGS, 
FWRI, USF College of Marine Sciences, NOAA). This strategic investment allowed USFSP to hire core science faculty and purchase scientific equipment. A new Science and Technology (S\&T) Building has been funded by the SUS BOG and the building is now operational. This facility provides needed teaching and research laboratory space to expand science and health programming. Moreover, USFSP has now initiated a new B.S. degree program in the Health Sciences aimed at students who will pursue careers or further e study in the paramedical fields. Two new faculty have been hired to support this new degree program through differential tuition funds. In addition, the USFSP College of Education will expand its current programs by initiating a new degree, an M.S. in Middle Grades STEM Education for practicing middle grades math and science teachers. Studies have clearly shown that the middle grades (4-9) represent the greatest source of "leaks" in the STEM pipeline - that is, these grades are where most students abandon their plans to pursue careers or further study in the STEM fields. The USFSP M.S. in Middle Grades STEM will enable USFSP to offer in-depth content and innovative pedagogies in science and mathematics courses and will include technological content knowledge in the middle grades that is necessary to provide future math and science teachers with tools to enhance student performance (and thus retention) in these key grades.

\section{Description of outcome(s) anticipated or dashboard indicator(s) to be} improved: (Be specific. For example, if this issue focuses on improving retention rates, indicate the current retention rate and the expected increase in the retention rate. In addition, identify the following, if applicable.)

The request for the BS in Biology will address Dashboard Metric \#5 (Degrees Awarded in STEM (Baccalaureate), through awarding of degrees in this area for the first time (see estimated numbers below). This new degree will enable USFSP to be more in line with its peer institutions in STEM degree production.

The request for the MS in Middle Grades STEM Education will have a salient effect on Dashboard Metric \#6 (Degrees Awarded in Specified Education Critical Shortage (Graduate)) by enabling students to pursue advanced education degrees to strengthen math/science/technology teaching at a key point in the STEM pipeline.

1. Number of Headcount Students receiving services or participating in the program by year, for the next five years:

Biology 201230
STEM Education 10 
Number of FTE Students receiving services or participating in the program by year for the next five years:

Biology

$2012 \quad 22.5$

$2013 \quad 26.25$

$2014 \quad 45$

$2015 \quad 63.75$

201675
STEM Education

10

10

12

12

15

Additional degrees, if any, produced as a result of this initiative: (Indicate the additional number of Bachelor's, Master's, Doctoral, \& Professional degrees to be produced by school year.)

\begin{tabular}{llc} 
BS in Biology & MS in STEM Educa \\
\hline 2012 & 0 & 0 \\
2013 & 10 & 5 \\
2014 & 25 & 10 \\
2015 & 35 & 10 \\
2016 & 50 & 15
\end{tabular}

Other outcomes:

\section{Facilities:}

A. Does this issue require an expansion or construction of a facility? No, a Science and Technology Building project is completed and will support this initiative.

B. If yes, is the project identified on the Capital Improvement List? If so, identify the project, fiscal amount, year requested, and priority number.

\begin{tabular}{|l|c|c|c|}
\hline & Facility Project Title & Fiscal Year & Amount Requested \\
\hline 1. & & & \\
\hline 2. & & & \\
\hline
\end{tabular}




\section{State University System \\ Florida Board of Governors \\ Instructions for Completing the Revised Operating Budget (OB) Form I}

The OB Form I is designed to capture the data needed to align a university's operating budget issue with the goals and objectives of the State University System (SUS) Strategic Plan and the New Florida Initiative.

Each university should submit one sequential priority list of all budget issues for the university. Any issues unique to a branch campus or a special unit (e.g., IFAS, health science center) should be incorporated into the single university priority list, even if the university decides to separate the base allocation into prorated amounts for each branch campus or special unit.

For each budget issue, please indicate the primary goal from the SUS Strategic Plan that the issue will address, and complete the form according to the instructions provided.

Keep all responses brief. All issues must have been identified in the 2011 University Work Plan submitted to the Board of Governors and must align with the goals and objectives of the SUS Strategic Plan and the New Florida Initiative. 


\section{State University System \\ Education and General \\ 2011-2012 Legislative Operating Budget Issue \\ Form I}

\begin{tabular}{|l|l|}
\hline University: & USF St. Petersburg \\
Work Plan Issue Title: & $\begin{array}{l}\text { Staff for Programs in Biology and } \\
\text { Middle Grades STEM Teaching }\end{array}$ \\
\hline $\begin{array}{l}\text { Priority Number } \\
\text { Recurring Funds Requested: }\end{array}$ & $\mathbf{1}$ \\
Non-Recurring Funds Requested: & $\mathbf{\$ 3 5 9 , 4 5 0}$ \\
Total Funds Requested: & $\mathbf{\$ 0}$ \\
& $\mathbf{\$ 3 5 9 , 4 5 0}$ \\
& $\begin{array}{l}\text { Note: Priority } 1 \text { contains } \$ 699,802 \text { for this issue for a } \\
\text { total of } \$ 1,609,101 \text { to complete this issue as described }\end{array}$ \\
\hline
\end{tabular}

Although an issue might address multiple SUS Strategic Plan Goals, please check a single primary goal that this issue will address:

Access to and Production of Degrees (Examples of issues that might support this goal could include services such as outreach programs, new enrollment growth, new elearning opportunities, or increased financial aid to improve student access; academic tracking, advising, tutoring, supplemental instruction, or other support services to improve undergraduate retention and graduation; or enhanced support to develop competitive recruitment packages for recruiting and retaining outstanding graduate and professional students.)

Meeting Statewide Professional and Workforce Needs (Examples of issues that might support this goal could include services that focus on the recruitment and retention of highly qualified students and faculty in disciplines associated with high-skill, high-wage jobs (e.g., STEM fields) or other areas of strategic emphasis in the State University System.)

Building World-Class Academic Programs and Research Capacity (Examples of issues that might support this goal could include focused support for academic programs on the cusp of national or international preeminence; support to achieve specialized accreditation in specific disciplines; new and/or expanded research initiatives built on the core strengths of the institution; or focused support to more quickly move cutting-edge university research to application and/or commercialization.)

\section{Meeting Community Needs and Fulfilling Unique Institutional}

Responsibilities (Examples could include issues important to a region or specific to an institution's mission - e.g., extension services, service learning initiatives, lifelong 
learning opportunities, community engagement initiatives, or targeted degree programs to meet regional needs.)

\section{Need and Justification:}

A. Identify the need as addressed explicitly in the $\mathbf{2 0 1 0}$ University Work Plan, and indicate where this budget issue is referenced in the Plan.

This request addresses a vital need for graduates with STEM degrees and for qualified science and mathematics teachers, particularly in the middle grades. This need is well-documented for Pinellas County, for the broader Tampa Bay region, and for the State of Florida as a whole. The degrees proposed in Biology (BS) and in STEM teaching (MS in Middle Grades Math and Science) were referenced in the 2010 university Work Plan under New Academic Degree Program Proposals - Next Three Years which called for initial enrollment in Fall 2012. They were also referenced in the Work Plan section on Windows of Opportunity/Unique Challenges. USFSP has reviewed these degree program plans and has revised the MS in Middle Grades Math and Science to be an MS in Middle Grades STEM Education which better reflects the inclusion of technology education in the planned degree. The BS in Biology is currently in the approval process by the USF System Board of Trustees.

B. Indicate how this budget issue aligns with the goal selected above from the SUS Strategic Plan.

The State of Florida has identified critical workforce shortages in the science, technology, engineering, mathematics, and medical (STEMM) fields that include Science and Math Teaching. This requested funding will help sustain and enhance USF St. Petersburg's initiative to initiate a new undergraduate degree in Biology and a new Masters degree in Middle Grades STEM Education. This proposal builds on USFSP's existing BS degrees in Environmental Science and Health Sciences and leverages the successful Middle Grades Digital Mathematics initiative (currently a graduate certificate) which has received funding from the Helios and Progress Energy Foundations. The proposal adds staff support for additional capacity in the sciences and in science and math education that will maximize the use of USFSP's Science and Technology Building that provides needed teaching classroom and laboratory space. 
C. Indicate how this budget issue aligns with the objectives of the New Florida initiative.

This request aligns directly with three of the objectives of the New Florida initiative

1. Focus each university on fulfilling its distinctive mission (research, degree production, solving Florida's problems, or some combination).

USF St. Petersburg is well-positioned to fulfill its distinctive mission as a student-centered, regional comprehensive university oriented to addressing the problems of the region and the state.

3. Focus half of the new funding on targeted degrees, such as Science, Technology, Engineering, and Math programs.

4. Focus half of the new funding on developing a pool of graduates with degrees needed for regional and statewide development (business, nursing, computing, construction, architecture, education, etc.) and create a pool of degreed citizens with creative and analytical thinking skills.

The request speaks directly to these two objectives through production of graduates in the STEM areas (Biology and STEM Education). USFSP has ample empirical evidence that its graduates possess highly developed creative and analytical thinking skills.

\section{Description:}

A. Description of service or program to be provided: (Include whether this is a new or expanded service/program. If expanded, what has been accomplished with the current service/program?)

USF St. Petersburg will initiate a new B.S. in Biology. USFSP already provides most of the courses for this degree but will need additional staff to support new, advanced courses in areas such as biochemistry, comparative physiology, limnology, and plant molecular biology. . USFSP requests funding to provide staff salaries and support for approximately 20 course sections per semester in these subjects. The request includes five (5) full-time staff to support courses and laboratories as well as to provide additional staff support for student research. For the new M.S. in Middle Grades STEM Education, the requested funding will provide two (2) full-time staff members with expertise in technologybased instruction in STEM fields.

\section{B. Description of current university initiatives and resources that will strengthen the provision of this service or program:}


USFSP created a Program of Distinction in Environmental Science, Policy, and Geography (ESPG) in 2003 to expand its science programs and leverage the expertise of its current partners on campus (USGS, FWRI, USF College of Marine Sciences, NOAA). This strategic investment allowed USFSP to hire core science faculty and purchase scientific equipment. A new Science and Technology (S\&T) Building has been funded by the SUS BOG and the building is now operational. This facility provides needed teaching and research laboratory space to expand science and health programming. Moreover, USFSP has now initiated a new B.S. degree program in the Health Sciences aimed at students who will pursue careers or further e study in the paramedical fields. Two new faculty have been hired to support this new degree program through differential tuition funds. In addition, the USFSP College of Education will expand its current programs by initiating a new degree, an M.S. in Middle Grades STEM Education for practicing middle grades math and science teachers. Studies have clearly shown that the middle grades (4-9) represent the greatest source of "leaks" in the STEM pipeline - that is, these grades are where most students abandon their plans to pursue careers or further study in the STEM fields. The USFSP M.S. in Middle Grades STEM will enable USFSP to offer in-depth content and innovative pedagogies in science and mathematics courses and will include technological content knowledge in the middle grades that is necessary to provide future math and science teachers with tools to enhance student performance (and thus retention) in these key grades.

\section{Description of outcome(s) anticipated or dashboard indicator(s) to be} improved: (Be specific. For example, if this issue focuses on improving retention rates, indicate the current retention rate and the expected increase in the retention rate. In addition, identify the following, if applicable.)

The request for the BS in Biology will address Dashboard Metric \#5 (Degrees Awarded in STEM (Baccalaureate), through awarding of degrees in this area for the first time (see estimated numbers below). This new degree will enable USFSP to be more in line with its peer institutions in STEM degree production.

The request for the MS in Middle Grades STEM Education will have a salient effect on Dashboard Metric \#6 (Degrees Awarded in Specified Education Critical Shortage (Graduate)) by enabling students to pursue advanced education degrees to strengthen math/science/technology teaching at a key point in the STEM pipeline.

1. Number of Headcount Students receiving services or participating in the program by year, for the next five years: 
Biology

201230

$2013 \quad 35$

$2014 \quad 65$

201585

2016100
STEM Education

10

10

15

15

20

Number of FTE Students receiving services or participating in the program by year for the next five years:

\begin{tabular}{llr}
\multicolumn{2}{c}{ Biology } & STEM Ed \\
\hline 2012 & 22.5 & 10 \\
2013 & 26.25 & 10 \\
2014 & 45 & 12 \\
2015 & 63.75 & 12 \\
2016 & 75 & 15
\end{tabular}

Additional degrees, if any, produced as a result of this initiative: (Indicate the additional number of Bachelor's, Master's, Doctoral, \& Professional degrees to be produced by school year.)

BS in Biology MS in STEM Education

$\begin{array}{lll}2012 & 0 & 0 \\ 2013 & 10 & 5 \\ 2014 & 25 & 10 \\ 2015 & 35 & 10 \\ 2016 & 50 & 15\end{array}$

Other outcomes:

\section{Facilities:}

A. Does this issue require an expansion or construction of a facility?

No, a Science and Technology Building project is completed and will support this initiative.

B. If yes, is the project identified on the Capital Improvement List? If so, identify the project, fiscal amount, year requested, and priority number.

\begin{tabular}{|l|c|c|c|}
\hline & Facility Project Title & Fiscal Year & Amount Requested \\
\hline 1. & & & \\
\hline 2. & & & \\
\hline
\end{tabular}

